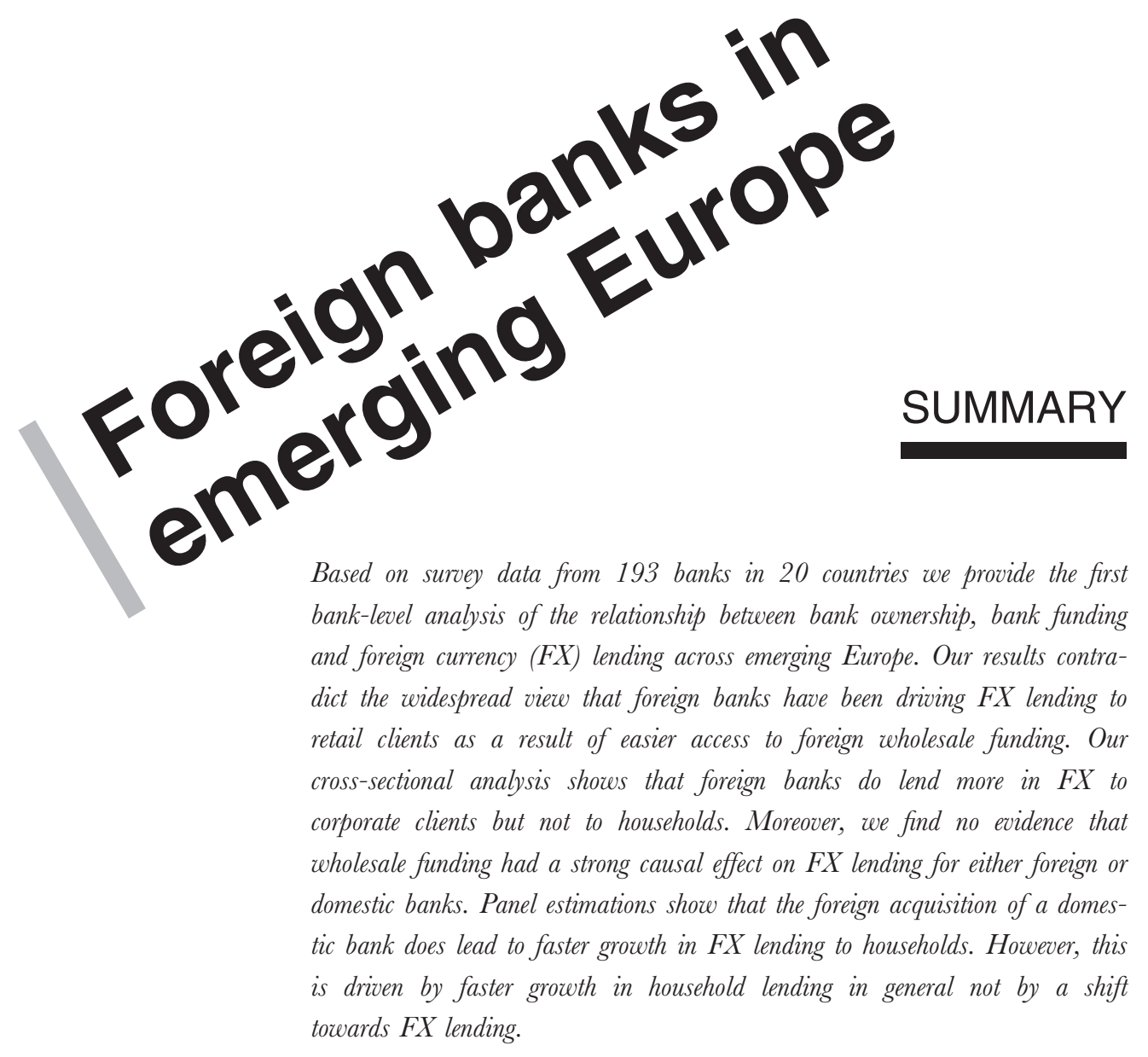

- Martin Brown and Ralph De Haas 



\title{
Foreign banks and foreign currency lending in emerging Europe
}

\author{
Martin Brown and Ralph De Haas
}

University of St Gallen; European Bank for Reconstruction and Development

\section{INTRODUCTION}

Unhedged foreign currency (FX) borrowing is seen as a major threat to financial stability in emerging Europe. More than $80 \%$ of all private sector loans in Belarus, Latvia and Serbia are currently denominated in (or linked to) a foreign currency and the share of FX loans also exceeds that of domestic currency loans in various other countries including Bulgaria, Hungary and Romania (European Bank for Reconstruction and Development (EBRD), 2010. FX borrowing throughout the region is dominated by retail loans - household mortgages, consumer credit and small business loans - to clients which typically have their income and assets in local currency. It is therefore not surprising that national authorities have taken measures to dis-

\footnotetext{
This paper was presented at the 53rd Panel Meeting of Economic Policy in Budapest. We would like to thank Asel Isakova and Veronika Zavacka for helpful statistical assistance and László Halpern, Olena Havrylchyk, Maria Soledad Martinez Peria, Alexander Popov, Marta Serra Garcia, Karolin Kirschenmann, Cédric Tille, Aaron Tornell, Paul Wachtel, Frank Westermann, Jeromin Zettelmeyer, three anonymous referees, and participants at the EBRD Research Seminar, the XIX International Tor Vergata Conference on Money, Banking and Finance, the EBRD-Reinventing Bretton Woods Committee Conference on Developing Local Currency Finance, and the 53rd Economic Policy Panel Meeting for useful comments. The views expressed are those of the authors and do not necessarily reflect those of the EBRD.

The Managing Editor in charge of this paper was Philip Lane.
} 
courage such loans. Supervisors in Hungary, Latvia and Poland have pushed banks to disclose the exchange rate risks of FX loans to clients and to tighten the eligibility criteria for such loans. In countries like Croatia, Kazakhstan and Romania stronger provisioning requirements were imposed on FX compared to local currency loans. Ukraine even completely banned FX lending to households in late 2008.

The call for policies to curb FX lending in Eastern Europe has intensified lately. In June 2010 the European Central Bank (ECB) stated that national efforts to rein in FX lending have had little impact and called for better coordination, including among home-country regulators of banks with subsidiaries in Eastern Europe. ${ }^{1}$ In this line of thinking FX lending is largely supply-driven, with FX funding of banks, often from their parent banks, at the heart of the problem. Surprisingly, the widespread view that FX lending in Eastern Europe is driven by foreign bank subsidiaries with access to ample FX funding has not yet been substantiated by empirical analysis. Comparisons of cross-country data document higher shares of FX lending in countries where banks have larger cross-border liabilities (Bakker and Gulde, 2010; Basso et al., 2010). However, whether such liabilities are causing or being caused by FX loans is hard to establish from aggregate data. Recent loan-level evidence for Bulgaria suggests that FX lending seems to be at least partly driven by customer deposits in FX, while wholesale funding in FX is a result rather than a cause of FX lending (Brown et al., 2010). It is unclear, however, whether this applies to a broad set of banks across the transition region.

The impact of foreign bank ownership on euroization and financial stability is a pertinent policy question. After the fall of the Berlin wall governments and development institutions actively supported the process of banking integration between Western and Eastern Europe. This support was based on the presumed positive impact of foreign bank entry on the efficiency and stability of local banking systems. The empirical evidence that emerged over the next two decades suggests that foreign banks indeed contributed to more efficient (Fries and Taci, 2005) and stable (De Haas and Van Lelyveld, 2006) banking sectors. However, the recent financial crisis has hit emerging Europe hard and questions have been raised about foreign banks' role in creating the economic imbalances, including large unhedged FX exposures, which made the region vulnerable. Regulation may help to counterbalance distortions - such as banks and borrowers that disregard the negative externalities of FX loans in terms of increasing the risk of a systemic crisis (see Rancière et al., 2010). Our paper contributes to this debate by using bank-level data to analyse to what extent FX lending in Eastern Europe is related to the presence of foreign banks and their funding.

Our main data source is the EBRD Banking Environment and Performance Survey (BEPS) conducted in 2005 and covering 95 foreign-owned and 98

${ }^{1}$ http://www.ecb.int/pub/pdf/other/financialstabilityreview201006en.pdf. 
domestic-owned banks in 20 transition countries. The BEPS elicits detailed information on the loan and deposit structure of each bank in 2001 and 2004, its risk management, as well as its assessment of local creditor rights and banking regulation. We match the BEPS data with financial statement data provided by Bureau van Dijk's BankScope database and with country-level indicators of the interest rate differential on foreign versus local currency funds, exchange rate volatility, inflation history, and the position of the country on the path towards EU accession.

While we do not cover the immediate run-up to and aftermath of the recent financial crisis, the observation period covered by our data is particularly interesting to study FX lending dynamics. During this period foreign currency lending to corporate clients was already widespread in Eastern Europe. For the banks in our sample the mean share of the corporate loan portfolio denominated in FX was $41 \%$ in 2001 and $44 \%$ in 2004 . During this three-year period we do, however, observe a significant increase in FX lending by banks in some countries (such as Belarus and Estonia) while in other countries (Kazakhstan, Russia) banks reduced FX lending. Furthermore, FX lending to households increased substantially across Eastern Europe during our observation period. Considering the banks in our sample, we find that the share of FX loans in their household loan portfolio increased from $28 \%$ in 2001 to $38 \%$ in 2004. Our data allow us to investigate to what extent these developments in FX lending to corporate and household clients are related to changes in the ownership and funding structure of banks.

Our results contradict the view that foreign banks have been driving FX lending to unsuspecting retail clients throughout Eastern Europe as a result of easier access to cross-border funding. First, our cross-sectional results suggest that while foreign banks do lend more in FX to corporate clients, they do not do so to households. Second, while the foreign acquisition of a bank does lead to faster growth in FX lending to retail clients, this is driven by faster growth in household lending per se and not by a redirecting of credit from domestic to foreign currency. Third, we find no evidence that wholesale funding had a strong causal effect on FX lending for any type of bank over the 2001-2004 period. The correlation between wholesale funding and FX lending at the bank level is weak. If anything, wholesale funding seems to be a result rather than a determinant of FX lending.

All in all, our findings tell us that foreign banks did not indiscriminately 'push' FX loans through their subsidiary network in the transition region, but followed a more subtle approach where FX lending is targeted to (corporate) clients that can carry the associated risks and to countries in which FX lending to households is attractive from a macroeconomic perspective. These results provide important insights to policymakers into the drivers of FX lending. In particular, they suggest that credible macroeconomic policies which encourage depositors to save in local currency may be more important than regulatory proposals to limit the wholesale funding of banks. 
The rest of the paper is organized as follows. Section 2 relates our study to the existing theoretical and empirical literature on FX lending. Section 3 describes our data and Section 4 presents our results. Section 5 sets out our policy conclusions.

\section{LITERATURE AND HYPOTHESES}

In this section we review existing theoretical and empirical studies on the currency denomination of bank loans, establish the hypotheses for our empirical analysis, and clarify our contribution to the literature.

\subsection{Bank funding}

The share of foreign currency assets held by a bank is typically related to the currency structure of its liabilities because banks are limited by prudential regulation in the FX exposure they can take. In a country with underdeveloped derivative markets for foreign currency exchange, banks' supply of FX loans therefore depends on their own access to foreign currency funding from depositors, financial markets and/or parent banks.

Recent evidence for Eastern Europe provides mixed results on the role of bank funding as a driver of FX lending. Basso et al. (2010) examine aggregate credit dollarization for 24 transition countries for the period 2000-2006. They find that countries in which banks have a higher share of foreign funding display a higher share of FX loans. De Haas and Naaborg (2006) and De Haas and Van Lelyveld (2006, 2010) show that parent bank funding, typically denominated in FX, influences the credit growth of foreign subsidiaries. To the extent that subsidiaries do not swap these funds into local currency, access to parent bank funding may have a positive impact on FX lending.

Luca and Petrova (2008) by contrast find no robust relation between aggregate lending in FX across transition countries and aggregate foreign liabilities of banks. They do, however, find a strong relation between aggregate levels of deposit dollarization and FX lending. Similarly, Brown et al. (2010) provide loan-level evidence that FX lending is driven by customer funding of banks in FX, rather than wholesale funding in FX.

\subsection{Banks' sensitivity to monetary conditions}

Banks' willingness to supply FX loans, and borrowers' demand for such loans, also depends on monetary conditions. On the demand side, firms and households are more likely to request FX loans when interest differentials are high and real exchange rate volatility is low. Luca and Petrova (2008) examine a model of credit dollarization in which risk-averse banks and firms choose an optimal portfolio of foreign and local currency loans. In line with other portfolio-choice models of 
foreign currency debt (Ize and Levy-Yeyati, 2003) they predict that banks offer more foreign currency loans when the volatility of domestic inflation is high and the volatility of the real exchange rate is low. Thus, in countries where the monetary authority has not established a credible reputation for pursuing price stability banks may prefer to make FX loans. As memories of bouts of (hyper)inflation are persistent, high inflation may lead to the entrenched use of FX even when economies stabilize (Kokenyne et al., 2010).

Cross-country comparisons of aggregate credit indeed document a strong role for monetary conditions in explaining the use of foreign currency in emerging economies. Most recently, Luca and Petrova (2008) analyse the aggregate share of FX loans for 21 transition countries of Eastern Europe and the former Soviet Union between 1990 and 2003. They find that the aggregate share of FX loans is positively related to interest rate differentials and domestic monetary volatility and negatively related to the volatility of the exchange rate. Work by Arteta (2005) on a broad sample of low-income countries, as well as Barajas and Morales (2003) and Kamil (2009) on Latin America, confirms the hypothesis that higher exchange rate volatility reduces credit dollarization.

Firm-level studies find more mixed results concerning the impact of monetary conditions on the currency composition of firm debt. Keloharju and Niskanen (2001) and Allayanis et al. (2003) find that the use of FX debt by corporate firms is strongly related to interest rate differentials. Brown et al. (2011) by contrast find only a weak impact of interest rate differentials and no impact of exchange rate volatility on the use of FX loans among small firms in transition economies.

\subsection{Bank ownership and client structure}

A bank's propensity to lend in FX also reflects the demand it encounters for FX loans from its clients. This means that to the extent that foreign and domestic banks serve different types of clients they may also face a different demand for FX denominated loans. Goswami and Shrikande (2001) show theoretically how firms may use foreign currency debt as a hedging instrument for the exchange rate exposure of their revenues. ${ }^{2}$ Cowan (2006) and Brown et al. (2009b) consider firms' choices of loan currency in models where the cost of foreign currency debt is lower than the cost of local currency debt. Cowan (2006) shows that firms are more likely to choose foreign currency debt the higher the interest rate differential, the larger their share of income in foreign currency and the lower their distress costs in case of default. The incentive to take foreign currency loans is weaker when the volatility

\footnotetext{
2 The model assumes uncovered interest rate parity, i.e. differences in nominal interest rates are cancelled out by changes in the exchange rate so that the cost of foreign and local currency borrowing is identical. In such a model interest rate differentials do not motivate foreign currency borrowing. However, evidence suggests that this parity does not hold for many currencies (Froot and Thaler, 1990; Isard, 2006).
} 
of the exchange rate is higher, as this increases the default risk on unhedged loans. Brown et al. (2009b) show that not only firms with foreign currency income, but also firms with high income in local currency (compared to their debt service burden) are more likely to choose foreign currency loans, as their probability to default due to exchange rate movements is lower. They also examine the impact of bankfirm information asymmetries on loan currency choice, showing that when lenders are imperfectly informed about the currency or level of firm revenue, local currency borrowers may be more likely to choose foreign currency loans. ${ }^{3}$ While focused on commercial loans, the models of Cowan (2006) and Brown et al. (2009b) are also relevant for FX lending to households. They predict that households with assets denominated in foreign currency, such as real estate in many countries, as well as households with FX income or high income to debt service levels are more likely to borrow in foreign currency.

A broad set of studies confirm that the use of FX debt is related to borrower characteristics, in particular borrower income structure. Large firms have been shown to match loan currencies to those of their sales in the US (Kedia and Mozumdar, 2003), Europe (Keloharju and Niskanen, 2001), Latin America (Martinez and Werner, 2002; Gelos, 2003; and Benavente et al., 2003) and East Asia (Allayannis et al., 2003).

More recent evidence suggests that the use of a foreign rather than a local currency loan by retail clients is also strongly related to borrower characteristics. Brown et al. (2011) examine the currency denomination of the most recent loan received by 3,105 small firms in 24 transition countries. They find strong evidence that the choice of an FX loan is related to FX cash flow. In contrast, they find only weak evidence that FX borrowing is affected by firm-level distress costs or financial opaqueness. Brown et al. (2010) examine requested and granted loan currencies using credit-file data for over 100,000 loans to small firms in Bulgaria. They show that firms with revenue in foreign currency, lower leverage and lower distress costs are more likely to ask for an FX loan, and are more likely to receive such a loan. Beer et al. (2010) examine survey data covering over 2,500 Austrian households and find that those households with higher wealth, higher income and better education are more likely to have foreign currency (CHF) rather than local currency (EUR) mortgages. Fidrmuc et al. (2011) show that the intention of households to take FX loans in Eastern Europe is related to household age, education and savings in FX. Finally, Degryse et al. (2011) provide evidence that suggests that FX lending in Poland is related to bank ownership. Examining a dataset on Polish banks for the period 1996-2006 they find that in particular greenfield foreign banks provide more FX loans than domestic banks.

\footnotetext{
${ }^{3}$ Banks may not be able to verify the income sources of small firms which do not keep detailed and audited financial records (Berger and Udell, 1998). This information asymmetry may be particularly pressing in countries with weak corporate governance (Brown et al., 2009a) and a strong presence of foreign banks which have less knowledge about local firms (Detragiache et al., 2008).
} 
This paper contributes to the empirical literature on foreign currency lending and borrowing by providing bank-level evidence on how FX lending is impacted by banks' funding structure, sensitivity to the macroeconomic environment, and ownership structure. We use our dataset to test three main hypotheses: (i) Access to FX denominated wholesale and deposit funding has a positive impact on FX lending; (ii) Banks are more likely to lend in FX in countries with unstable macro economic conditions, and (iii) Foreign ownership has an independent positive impact on banks' proportion and quantity of FX lending, e.g. because foreign banks are more likely to attract clients with a demand for currency hedging.

By testing these hypotheses with bank-level data for a broad set of transition economies, we provide micro-evidence on FX lending to both firms and households and complement cross-country studies of aggregate FX lending such as Luca and Petrova (2008) and Basso et al. (2010), firm-level and household-level studies such as Brown et al. (2011) and Fidrmuc et al. (2011), as well as bank-level studies for individual countries such as Brown et al. (2010) and Degryse et al. (2011).

\section{DATA}

\subsection{The Banking Environment and Performance Survey (BEPS)}

Our main data source is the EBRD Banking Environment and Performance Survey (BEPS) conducted in 2005 across 20 transition countries. The BEPS elicits detailed information on the loan and deposit structure, including the currency denomination, of a large number of banks in 2001 and 2004. Information was also collected on banks' risk management and their assessment of creditor rights and banking regulation. BEPS further provides detailed information on bank ownership, which allows us to differentiate between three ownership categories: banks with majority domestic ownership, newly created foreign banks (greenfields), and privatized banks with majority foreign ownership (takeovers).

From the 1,976 banks operating in the transition region in 2005 the EBRD approached the 419 banks which were covered by Bureau van Dijk's BankScope database. These banks represent more than three-quarters of all banking assets in the transition region. Of these banks 220 agreed to participate in the BEPS. There are only small differences between banks that agreed to participate in BEPS and those that declined. De Haas et al. (2010) provide a detailed description of the BEPS and how it provides a representative picture of the underlying banking population in emerging Europe in terms of bank size and bank ownership. Both in BankScope and in BEPS 7\% of the banks are state-owned and while in BankScope $47 \%$ of all banks are foreign owned, in BEPS 55\% are foreign owned. Finally, while in BankScope 45\% of all banks are private domestic banks, 38\% of all banks in BEPS belong to this category. There is only a weak relationship between bank size and inclusion in BEPS. 
The dataset we use in this paper excludes 27 banks for which information on the currency composition of loans was not available. We thus have a sample of 193 banks from 20 countries, of which 98 are domestic banks (private or state-owned), 44 greenfield foreign banks, and 51 are foreign banks that are the result of a takeover of a former domestic bank. Table 1 shows the geographical distribution of these banks over the transition region. The sample is evenly distributed over the three main sub-regions: Central Europe and the Baltic countries (62 banks), South Eastern Europe (72 banks), and the Commonwealth of Independent States (CIS) (59 banks). In terms of ownership, our sample also reflects that the banking sector in the CIS has seen less foreign direct investment compared to the other parts of the transition region.

From the BEPS we yield four indicators of bank-level foreign currency lending as our dependent variables: $F X$ share corporates is the share of a bank's outstanding loan portfolio to firms which is FX denominated. Likewise, $F X$ share households is the share of the outstanding loan portfolio to households denominated in FX. We

Table 1. Bank ownership by country

\begin{tabular}{|c|c|c|c|c|c|}
\hline & Total & $\begin{array}{l}\text { Foreign } \\
\text { greenfield }\end{array}$ & $\begin{array}{l}\text { Foreign } \\
\text { takeover }\end{array}$ & Domestic & $\begin{array}{l}\text { Foreign } \\
\text { acquired }\end{array}$ \\
\hline Central Europe and Baltics (CEB) & 62 & 15 & 26 & 21 & 15 \\
\hline Czech Republic & 7 & 0 & 4 & 3 & 3 \\
\hline Estonia & 5 & 0 & 4 & 1 & 1 \\
\hline Hungary & 3 & 3 & 0 & 0 & 0 \\
\hline Latvia & 16 & 1 & 6 & 9 & 2 \\
\hline Lithuania & 5 & 0 & 3 & 2 & 2 \\
\hline Poland & 13 & 7 & 4 & 2 & 3 \\
\hline Slovak Republic & 6 & 3 & 3 & 0 & 2 \\
\hline Slovenia & 7 & 1 & 2 & 4 & 2 \\
\hline South Eastern Europe (SEE) & 72 & 22 & 22 & 28 & 13 \\
\hline Albania & 4 & 3 & 1 & & 1 \\
\hline Bosnia & 11 & 3 & 4 & 4 & 2 \\
\hline Bulgaria & 11 & 3 & 6 & 2 & 5 \\
\hline Croatia & 11 & 4 & 1 & 6 & 1 \\
\hline Macedonia & 6 & 0 & 2 & 4 & 2 \\
\hline Romania & 11 & 5 & 5 & 1 & 2 \\
\hline Serbia & 18 & 4 & 3 & 11 & 0 \\
\hline $\begin{array}{l}\text { Commonwealth of Independent } \\
\text { States (CIS) }\end{array}$ & 59 & 7 & 3 & 49 & 0 \\
\hline Belarus & 9 & 1 & 2 & 6 & 0 \\
\hline Kazakhstan & 7 & 0 & 0 & 7 & 0 \\
\hline Moldova & 8 & 0 & 1 & 7 & 0 \\
\hline Russia & 27 & 3 & 0 & 24 & 0 \\
\hline Ukraine & 8 & 3 & 0 & 5 & 0 \\
\hline Total & 193 & 44 & 51 & 98 & 28 \\
\hline
\end{tabular}

Note: The table reports the number of banks in our sample by country and ownership type. Foreign greenfield banks are foreign banks established from scratch, whereas Foreign takeover banks are foreign banks that are the result of a takeover of a domestic bank by a foreign strategic investor. Foreign acquired banks are takeover banks that were acquired in 2000, 2001 or 2002. Table 2 provides definitions and sources of all variables. 
measure both of these variables in 2004 and 2001 and use the 2004 values in our cross-sectional analysis and the 2004-2001 differences in our panel analysis. In our panel analysis we further employ two variables - FX growth corporates and $F X$ growth households - that measure the growth of the volume of FX loans over 2001-2004.

Figure 1 depicts the 2001 and 2004 values for $F X$ share corporates and $F X$ share households for each of the 193 banks in our dataset. It shows a strong correlation between the 2001 and 2004 proportion of corporate lending in FX. By contrast, during this period many banks experienced stronger changes in the currency denomination of their household loan portfolio. On average, the share of FX loans to households in our sample increased from $28 \%$ in 2001 to $38 \%$ in 2004 . However, as Figure 1 shows, these averages mask substantial heterogeneity in the development of household lending across banks.

While dynamics in FX lending continued after our sample period ended, we think that the period 2001-2004 - that is, the first half of the 2001-2007 credit boom in many parts of emerging Europe - is well-suited to study the determinants of FX lending as it set the scene for later developments. Table A1 in the Appendix displays country-level data on FX lending. It shows that in many countries the FX lending dynamics that took place during 2001-2004 continued during the later years. For instance, our data pick up both the trend towards more FX lending in
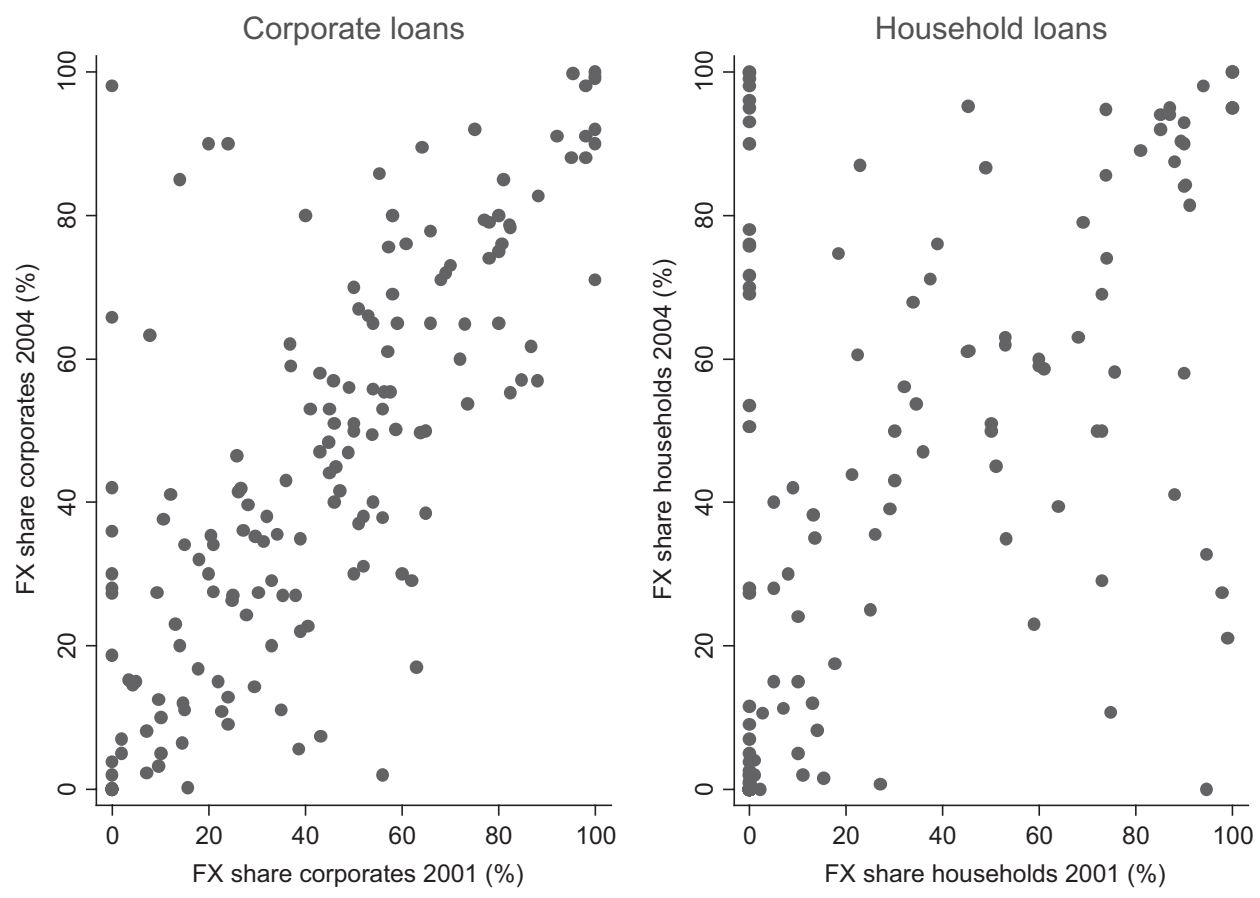

Figure 1. FX lending in 2001 and 2004

Note: This figure plots the 2001 values against the 2004 values for the variables $F X$ share corporates and $F X$ share households. Table 2 provides definitions and sources of all variables. 
Bulgaria, Estonia, Latvia and Serbia and the trend towards less FX lending in Albania, Kazakhstan and Russia. Indeed, the overall cross-country correlation between FX lending in 2004 and 2007 is very high at 0.79 and between 2007 and 2010 even 0.94 .

\subsection{Explanatory variables}

Table 2 provides a description and the source of all variables we use in our empirical analysis. We construct bank ownership dummies that indicate whether a bank is a Foreign greenfield bank, a Foreign takeover bank, or a Domestic bank in 2004. Information to construct these dummies is taken from BEPS and where needed supplemented with information from banks' websites. We also create a variable Foreign held which is 1 for all banks that were foreign-owned throughout 2000-2004 and 0 for all banks that were domestically owned throughout this period. Finally, we construct a dummy Foreign acquired that identifies banks acquired in 2000, 2001 or 2002.

We use two indicators of the funding structure of a bank. $F X$ deposits is taken from BEPS and directly captures the share of customer deposits which are FX denominated. Wholesale funding is taken from BankScope and captures non-customer liabilities as a share of total liabilities. We employ this variable as an indicator of wholesale funding in foreign currency. We think this is a reasonable assumption as much of the transition region remains characterized by very underdeveloped local currency bond and money markets (EBRD, 2010). As a result, banks find it difficult if not impossible to supplement their (mainly short-term) domestic deposit base with longer-term local-currency liabilities. Wholesale funding therefore tends to be FX denominated, as (the more reputable) banks attract FX debt in the international capital markets or, in the case of foreign bank subsidiaries, from their parent banks. De Haas and Naaborg (2006) show how centralized Treasuries operated by multinational banks such as SEB, Erste Bank, ING Bank and ABN Amro Bank form the main source of non-deposit funding for the subsidiaries of these banks in emerging Europe.

Both our measures of bank funding may be endogenous to FX lending. In our cross-sectional analysis we therefore add a specification in which we instrument both. Our instrument for Wholesale funding is the variable Internal ratings which indicates whether the bank used an internal ratings based approach in 2004. Banks that use such an approach tend to be relatively sophisticated and in a better position to attract wholesale funding. Our instrument for $F X$ deposits is the variable Corporate deposits which measures the share of customer deposits from firms. FX deposits may be directly related to a bank's focus on corporate clients as (exporting) firms tend to have more access to FX and deposit this at their bank. Section 4.1 provides details on our instrumentation strategy.

At the bank-level we control for bank size with the variable Assets which measures total bank assets in log USD. This indicator is taken from BankScope and is a 


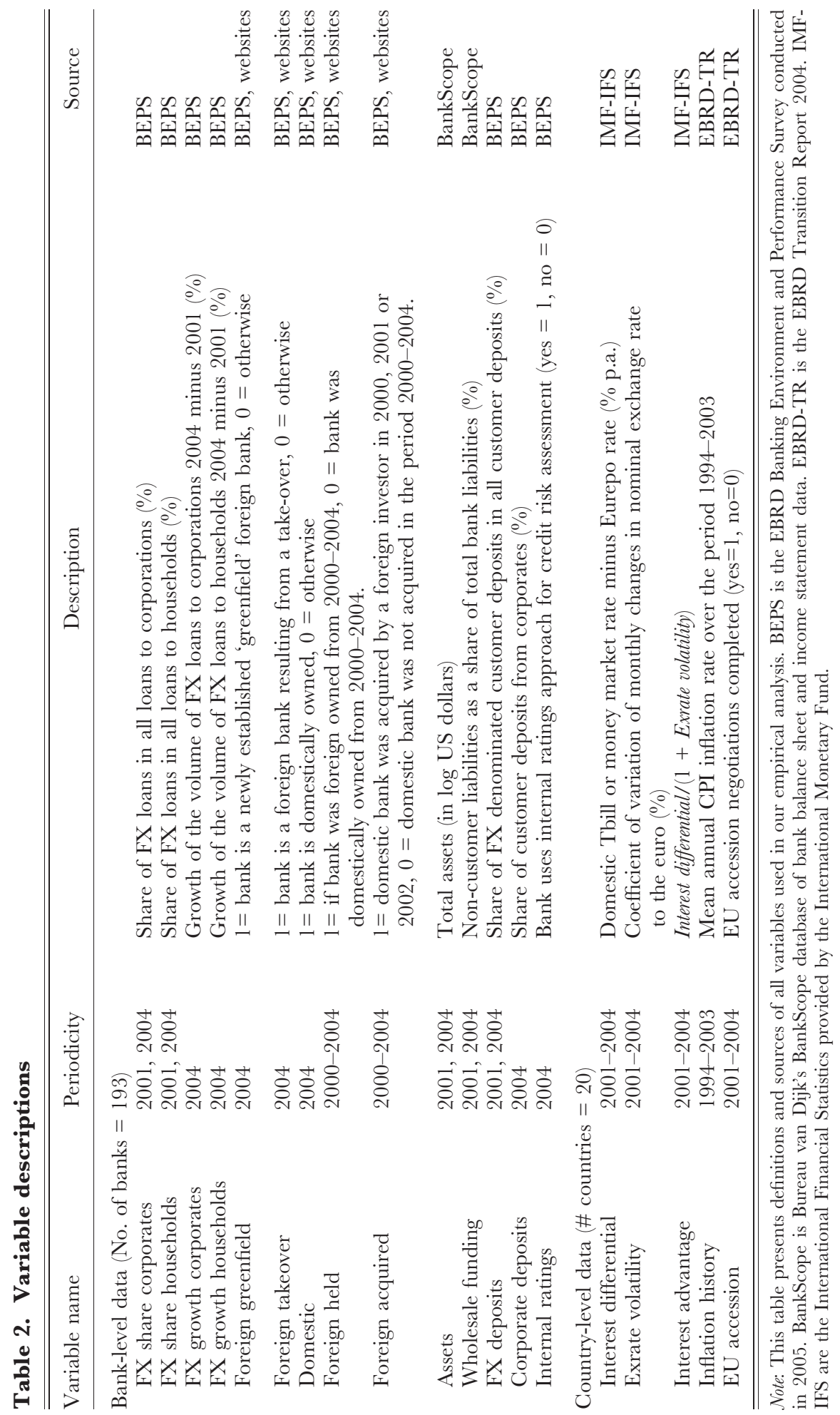


measure of both client structure and bank-funding structure. On the one hand, larger banks are more likely to serve large firms, which may have a higher demand for FX debt. On the other hand, larger banks may have better access to crossborder wholesale funding.

In our empirical analysis we alternatively employ country fixed effects and country-level explanatory variables to account for cross-country variation in macroeconomic conditions. Our country-level explanatory variables are taken from the EBRD Transition Report and the IMF International Financial Statistics. Interest differential is the difference between reference interest rates on the domestic currency and the euro. Exrate volatility captures the variation of month-on-month changes in the nominal exchange rate of the domestic currency to the euro. Interest advantage combines the preceding two variables into one summary measure of the relative advantage of borrowing in a foreign currency. It divides Interest differential by the Exrate volatility (plus 1) and can be seen as a reward-to-variability or Sharpe ratio that measures the benefit of borrowing in euro, rather than in the local currency, per unit of exchange rate risk.

Besides the above measures of contemporary monetary conditions we attempt to control for past and future macroeconomic stability which may affect FX lending. Inflation history measures the mean annual inflation rate over the preceding period 1994-2003. Lastly, we create a variable EU accession which indicates for each country and year in the 2001-2004 period whether a country had completed EU accession negotiations. This yearly score is then averaged over the sample period.

\subsection{Descriptive statistics}

Table 3 provides descriptive statistics for all our variables. Panel A reports summary statistics for the full sample as well as means by bank-ownership and region. Panel B shows summary statistics for our country-level variables. Table A2 in the Appendix provides a matrix of pair-wise correlations. Table 3 shows that in 2004, $44 \%$ of all corporate lending and $38 \%$ of all household lending by the banks in our sample was denominated in FX. Differences in the share of FX lending are substantial across banks, with some banks displaying no FX loans while other banks have their entire loan portfolio in FX. Between 2001 and 2004 there was an average increase of 3 and 10 percentage points, respectively, in the proportion of corporate and household loans denominated in FX.

The table confirms that foreign banks lend more in FX. However, there is a marked difference between lending to firms and to households. For corporate clients we see that in 2004 both greenfield and takeover foreign banks display a higher share of FX lending than domestic banks. Interestingly, the share of FX loans to firms by takeover banks converges to that of greenfield banks between 2001 and 2004, while FX lending by domestic banks to firms did not increase. For 
Table 3. Descriptive statistics

Panel A. Bank-level variables

\begin{tabular}{|c|c|c|c|c|c|c|c|c|c|c|c|}
\hline \multirow[b]{2}{*}{$\begin{array}{l}\text { Variable } \\
\text { name }\end{array}$} & \multicolumn{5}{|c|}{$\begin{array}{c}\text { Full sample } \\
\text { summary statistics }\end{array}$} & \multicolumn{3}{|c|}{$\begin{array}{c}\text { Means by } \\
\text { bank-ownership }\end{array}$} & \multicolumn{3}{|c|}{$\begin{array}{l}\text { Means by } \\
\text { region }\end{array}$} \\
\hline & Obs & Mean & Std. Dev. & Min & Max & $\begin{array}{l}\text { Green } \\
\text { field }\end{array}$ & $\begin{array}{l}\text { Take } \\
\text { over }\end{array}$ & Domestic & CEB & SEE & CIS \\
\hline \multicolumn{12}{|c|}{ Cross-sectional analysis: 2004} \\
\hline $\begin{array}{l}\text { FX share } \\
\text { corporates }\end{array}$ & 179 & 44.0 & 28.9 & 0 & 100 & 51.3 & 50.4 & 37.6 & 44.6 & 45.2 & 42.0 \\
\hline $\begin{array}{l}\text { FX share } \\
\text { households }\end{array}$ & 174 & 38.0 & 36.1 & 0 & 100 & 45.7 & 36.1 & 35.5 & 32.0 & 36.1 & 46.1 \\
\hline Assets & 187 & 20.0 & 1.6 & 16 & 24.1 & 20.1 & 20.7 & 19.7 & 20.9 & 19.5 & 19.8 \\
\hline $\begin{array}{l}\text { Wholesale } \\
\text { funding }\end{array}$ & 187 & 31.9 & 22.2 & 1 & 99 & 44.0 & 28.6 & 27.8 & 34.4 & 27.8 & 34.0 \\
\hline FX deposits & 176 & 41.7 & 23.6 & 0 & 99 & 43.0 & 37.2 & 43.4 & 34.9 & 49.3 & 39.8 \\
\hline $\begin{array}{c}\text { Corporate } \\
\text { deposits }\end{array}$ & 177 & 45.1 & 24.7 & 0 & 100 & 49.5 & 39.0 & 46.1 & 43.4 & 43.2 & 49.4 \\
\hline $\begin{array}{l}\text { Internal } \\
\text { ratings }\end{array}$ & 178 & 0.80 & 0.40 & 0 & 1 & 0.80 & 0.84 & 0.78 & 0.74 & 0.79 & 0.89 \\
\hline \multicolumn{12}{|c|}{ Panel analysis: 2004 minus 2001} \\
\hline $\begin{array}{l}\text { FX share } \\
\text { corporates }\end{array}$ & 166 & 2.5 & 20.4 & -54 & 98 & 0.7 & 10.0 & -0.1 & 5.3 & 4.2 & -2.1 \\
\hline $\begin{array}{l}\text { FX share } \\
\text { households }\end{array}$ & 158 & 9.8 & 32.4 & -95 & 100 & 11.5 & 9.6 & 9.2 & 3.2 & 10.9 & 15.3 \\
\hline $\begin{array}{l}\text { FX growth } \\
\text { corporates }\end{array}$ & 127 & 6.7 & 26.1 & -1 & 270 & 12.6 & 8.2 & 3.1 & 3.6 & 14.0 & 3.2 \\
\hline $\begin{array}{l}\text { FX growth } \\
\text { households }\end{array}$ & 77 & 4.7 & 5.9 & -1 & 33 & 4.1 & 6.1 & 4.2 & 4.0 & 5.4 & 5.0 \\
\hline Assets & 155 & 1.0 & 0.5 & -0.7 & 2.9 & 1.1 & 1.0 & 1.0 & 1.0 & 1.0 & 1.1 \\
\hline $\begin{array}{l}\text { Wholesale } \\
\text { funding }\end{array}$ & 155 & 3.0 & 15.3 & -42 & 50 & 4.5 & 5.4 & 0.9 & 4.1 & 4.0 & 0.6 \\
\hline FX deposits & 167 & -4.1 & 16.0 & -52 & 62 & -3.4 & -2.1 & -5.5 & -2.4 & -4.2 & -5.9 \\
\hline
\end{tabular}

Panel B. Country-level variables

\begin{tabular}{|c|c|c|c|c|c|c|c|c|}
\hline \multirow[b]{2}{*}{ Variable name } & \multicolumn{5}{|c|}{ Full sample summary statistics } & \multicolumn{3}{|c|}{ Means by region } \\
\hline & Obs & Mean & Std. Dev. & Min & Max & CEB & SEE & CIS \\
\hline \multicolumn{9}{|c|}{ Country-level variables: 2001-2004 averages } \\
\hline Interest differential & 20 & 6.9 & 9.2 & 0.4 & 37.4 & 2.9 & 7.8 & 12.0 \\
\hline Exrate volatility & 20 & 2.8 & 2.1 & 0.0 & 8.0 & 2.1 & 1.8 & 5.2 \\
\hline Interest advantage & 20 & 1.7 & 1.5 & 0.1 & 4.8 & 0.9 & 2.5 & 1.6 \\
\hline Inflation history & 20 & 60 & 93 & 2 & 371 & 11 & 42 & 165 \\
\hline EU accession & 20 & 0.2 & 0.3 & 0 & 0.5 & 0.5 & 0 & 0 \\
\hline
\end{tabular}

Note: This table provides summary statistics for the 2004 values and 2004-2001 differences of our bank-level and country-level variables. Region definitions CEB, SEE and CIS are in accordance with those listed in Table 1. Table 2 provides variable definitions and sources.

household loans we find that the share of FX lending increased strongly for all ownership types. In contrast to corporate lending, we also find that in 2004 the share of household loans in FX is similar for foreign takeover banks and domestic 
banks with both bank types displaying a lower level of FX loans than foreign greenfield banks. ${ }^{4}$

Looking at banks' funding structure, we find that on average $32 \%$ of total liabilities is Wholesale funding, while $42 \%$ of bank deposits are denominated in FX. Greenfield foreign banks rely much more on wholesale funding $(44 \%)$ compared to foreign takeover banks (29\%) or domestic banks (28\%). By contrast, the foreign currency share of deposits is similar for all bank types, indicating that the 'euroization' of deposits is mostly driven by the macroeconomic environment. Interestingly, during 2001-2004 the share of FX deposits in total deposits declined by about four percentage points.

To what extent is FX lending by the banks in our sample related to their funding structure? The scatter plots in Figure 2 provide some first insights into this issue. The figure shows no apparent bivariate relationship between the proportion of wholesale funding and FX lending. By contrast, banks with a large share of FX denominated customer deposits lend more in FX. In line with this, Table A2 in the Appendix shows that whereas the pair-wise correlation between wholesale funding
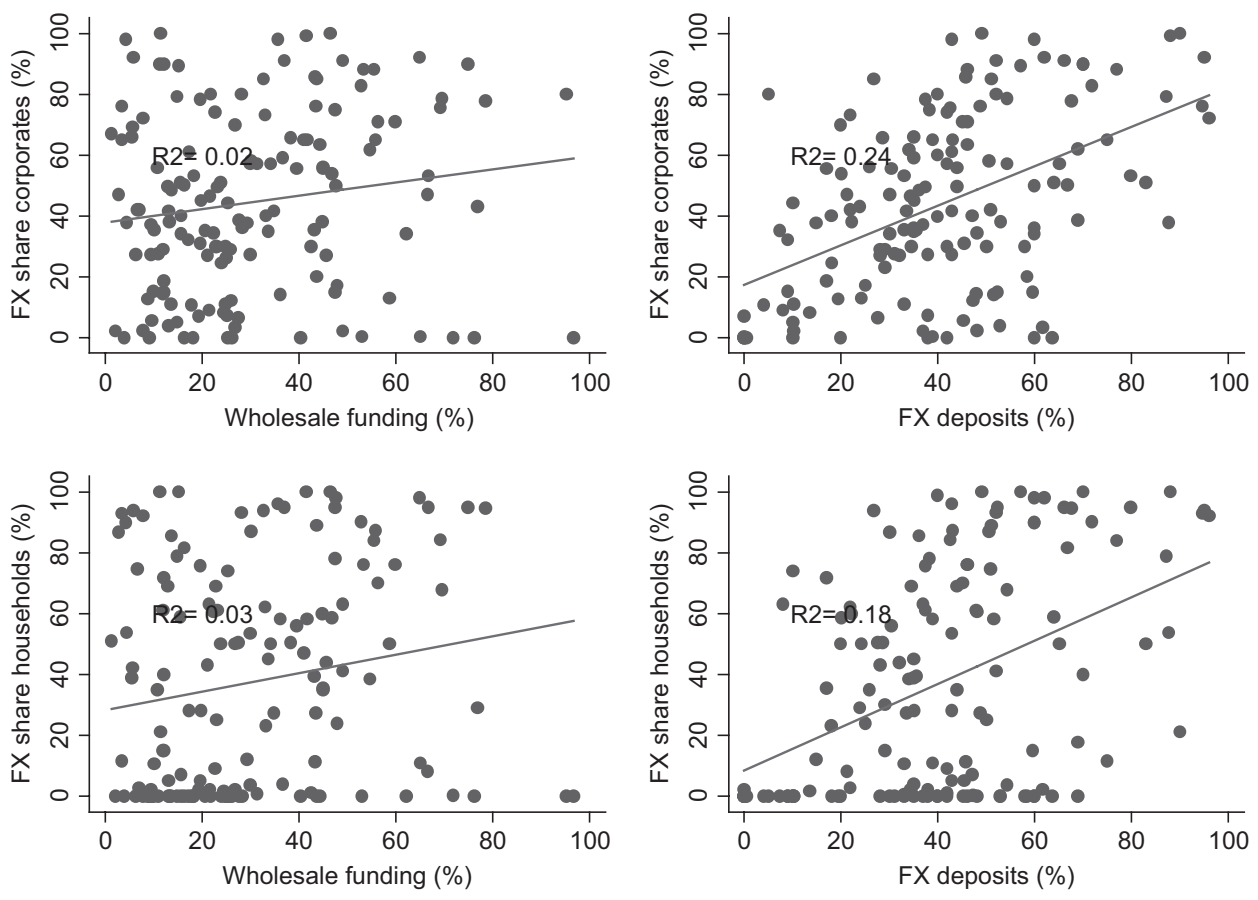

Figure 2. FX lending and bank funding in 2004

Note: This figure plots $F X$ share corporates and FX share households against Wholesale funding and $F X$ deposits. All data refer to 2004. For comparability with Figure 1 we include only banks with observations for $F X$ share corporates and FX share households in 2004 and 2001. Table 2 provides definitions and sources of all variables.

\footnotetext{
${ }^{4}$ Degryse et al. (2011) also find that in particular greenfield foreign banks provide more FX loans than domestic banks.
} 
and corporate and household FX lending is only $0.16(p=0.04)$ and 0.13 $(p=0.09)$, respectively, the correlations between the proportion of FX deposits and both types of FX lending are $0.44(p=0.00)$ and $0.43(p=0.00)$. This is in line with findings by Brown et al. (2010) and Fidrmuc et al. (2011) on the importance of FX deposits for FX lending.

\section{MULTIVARIATE RESULTS}

The cross-sectional and panel analyses in this section examine to what extent there is a causal relationship between foreign ownership, bank funding and FX lending.

\subsection{Cross-sectional variation in FX lending}

Table 4 provides a cross-sectional analysis of banks' share of FX lending to corporate clients (left-hand panel) and households (right-hand panel) in 2004. In line with the hypotheses developed in Section 2, we analyse the impact of bank ownership, bank funding and the macroeconomic environment. The first column in each panel displays an OLS specification in which the share of FX lending is explained by bank ownership, bank funding and bank size.

In Columns 2 and 7 we account for the endogeneity of a bank's funding structure by instrumenting our variables Wholesale funding and $F X$ deposits with Internal rating and Corporate deposits, respectively. Our analysis suggests that the chosen instruments are valid, strong and span our endogenous regressors. When we run second-stage regressions where we add these instruments as additional regressors they do not have an independent impact on FX lending, suggesting that the instruments are valid. Our instruments are highly correlated with the endogenous regressors in the first-stage regressions and thus relatively strong. Finally, the reported KleibergenPaap statistics show that our regression specification is not underidentified. Table A3 in the Appendix reports the first-stage results of our instrumental variable analysis.

In Columns 3-4 and 8-9 we add to this IV specification country-level indicators of the macroeconomic environment. Finally, in Columns 5 and 10 we interact these macroeconomic indicators with foreign bank ownership to examine whether foreign banks react differently to contemporaneous monetary conditions and long-term macroeconomic stability. ${ }^{5}$ As these two specifications also contain country fixed effects, we do not include the macroeconomic indicators as stand-alone variables but only when interacted with the bank-ownership variables.

\footnotetext{
${ }^{5}$ Since some banks provide no FX loans at all, we also ran models where we first estimate a probit regression and then a conditional OLS. This yields similar results to the unconditional OLS results reported in Table 4. The same holds when we estimate Tobit regressions. Note that the proportion of FX lending is naturally bound between 0 and 100 and not truly censored, which makes OLS a more appropriate estimation technique than Tobit regressions.
} 


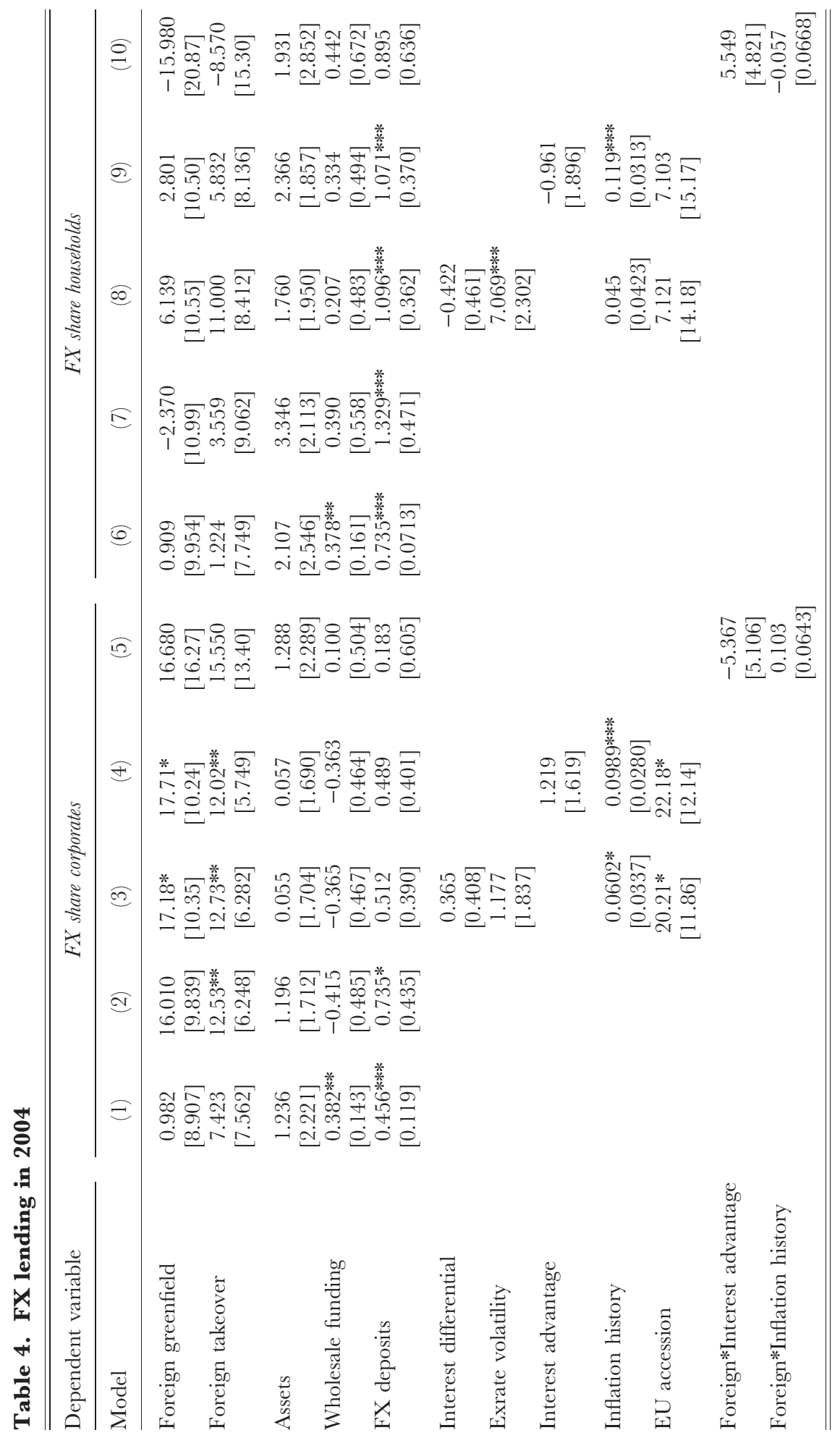




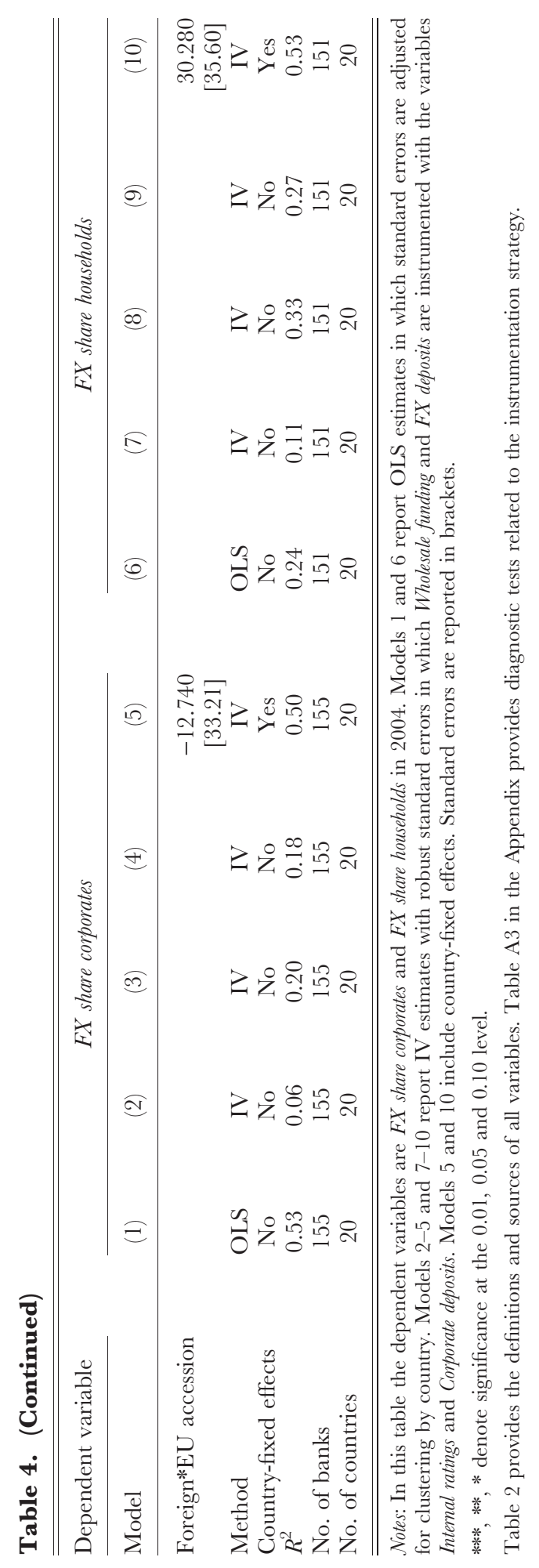


Table 4 displays four key findings. First, foreign ownership is associated with a higher share of FX loans to firms but not to households. Columns 2-4 show that greenfield (takeover) foreign banks lend 17 (12) percentage points more in FX than domestic banks. In sharp contrast, bank ownership does not impact FX lending to households. Why do foreign banks lend more in FX to firms but not to households? One reason may be that households are a relatively homogenous borrower group whereas firms are more diverse. Foreign banks may serve a different set of corporate clients with a higher demand for FX loans, for instance because they are larger and better diversified or because they have FX revenues that need to be hedged. Indeed, the BEPS data indicate that foreign banks lend significantly more to subsidiaries of international firms than domestic banks (see also De Haas et al. 2010).

Our second finding is that Wholesale funding of banks seems to be a result rather than a determinant of FX lending. The coefficients in Columns 1 and 6 suggest that there is a relation between wholesale funding and FX lending. However, once we account for the endogeneity of wholesale funding (by instrumenting it with Internal rating) its coefficient is no longer significant at any conventional level.

Our third finding is that there does seem to be a causal impact of foreign denominated customer deposits on FX lending. The coefficients reported in Columns 1 and 6, respectively, suggest that a 10 percentage point increase in $F X$ deposits by customers increases the share of FX loans to firms by $5 \%$ and to households by $7 \%$. Not surprisingly, the impact on $F X$ share corporates loses statistical and economic significance once we account for the potential endogeneity of deposits. This indicates that $F X$ deposits is partially endogenous, as FX lending to (international) firms and access to FX deposits by these firms is determined simultaneously.

Interestingly, and in line with this interpretation, the same instrumentation strategy does not reduce the significance of $F X$ deposits in the right-hand panel. In the case of lending to households, access to FX deposits is exogenous and has a causal impact on FX lending to retail clients. Note, however, that the coefficient becomes insignificant once we include country fixed effects in Column 10. Our result is thus mainly driven by between-country variation in FX deposits rather than betweenbank variation in access to FX deposits within countries. The impact of FX denominated customer deposits on the share of FX lending to households confirms recent findings by Brown et al. (2010) and Luca and Petrova (2008).

Our fourth finding is that long-term macroeconomic conditions rather than contemporaneous monetary conditions affect FX lending. In particular, we find that banks in countries with a history of high inflation (over the period 1994-2003) show a higher proportion of FX lending. This may suggest that in countries with 'inflation traumas' banks are more reluctant to lend in local currency. An alternative explanation is that FX lending is related to a history of real appreciation of the local currency. Our data show that in emerging Europe high levels of past inflation are associated with real appreciation of the local currency. Indeed, when we replace 
the variable Past inflation in Table 4 with the variable Trend appreciation, which measures the mean real appreciation of the local currency over the period 1994-2003, we find that FX lending is indeed higher in countries that have experienced trend appreciation in the past.

For FX lending to firms we also find that progress with EU accession, and the associated macroeconomic and institutional stabilization, had a positive effect on the proportion of FX lending. Progress towards EU accession may somewhat paradoxically have increased the incentives for denominating debt in FX as the 'certainty' of a euro exit, and the expectation of nominal exchange rate stability during the convergence trajectory, made FX lending more attractive even when interestrate differences came down at the same time. Indeed, in line with recent evidence by Brown et al. (2009), we find that neither interest-rate differentials nor nominal exchange-rate volatility is significantly related to FX lending. The main macro economic determinants seem to be past inflation and real appreciation as well as the expected stabilization of EU accession.

In Columns 5 and 10 we examine whether FX lending by foreign banks is more sensitive to the macroeconomic environment. Foreign banks may be more reluctant to lend in domestic currency if they mistrust macroeconomic policy more than domestic banks. We therefore interact our macroeconomic indicators with the dummy variable Foreign, which is 1 for greenfield and takeover foreign banks (while also including country fixed effects). ${ }^{6}$ Our results suggest that foreign banks are not significantly more sensitive to the host-country macroeconomic environment than domestic banks.

Throughout much of central and south-eastern Europe the euro has been the main currency used for FX lending and we have therefore calculated our variables Interest rate differential, Exrate volatility, and Interest advantage relative to euro interest and exchange rates. However, in a number of countries many FX loans are denominated in either the Swiss franc (Hungary and Poland) ${ }^{7}$ or the US dollar (Belarus, Kazakhstan, Moldova, Russia and Ukraine). As a robustness test we therefore ran the regressions in Table 4 while replacing the exchange rate of the local currency vis-à-vis the euro with the exchange rate vis-à-vis the Swiss franc or the US dollar for the countries mentioned above. Our results remain virtually unchanged in terms of economic and statistical significance, reflecting the co-movement of these foreign currencies relative to the currencies of emerging Europe during 2001-2004.

As the BEPS survey does not cover all bank types in all countries, the effects of foreign bank-ownership indentified in Table 4 may simply be capturing omitted cross-country differences in financial sector, economic or institutional conditions. To assess whether we are mixing ownership effects with country effects we run

\footnotetext{
${ }^{6}$ We do not distinguish between greenfield and takeover foreign banks here because unreported regression results show no significant differences in the interaction effects between these two types of foreign banks.

7 Brown et al. (2009c) show that Poland and Hungary are the only two transition economies with a significant share of foreign currency loans denominated in Swiss francs.
} 
robustness tests where we exclude those countries for which we only have information on one type of bank. In further robustness tests we also control for whether the bank is a member of a multinational bank network, as well as for additional characteristics (mean loan size, share of real-estate loans) of the loan portfolio held by each bank. Each of these robustness tests confirms our cross-sectional finding that foreign bank ownership is associated with more FX lending to corporates (but not to households).

Summing up, our cross-sectional results contradict widespread views concerning foreign bank ownership, bank funding and FX lending. First, we find that foreign banks lend more in FX to corporate clients but not to retail clients. Second, we find only a very weak relationship between wholesale funding and FX lending, with the former being a result, rather than a determinant of the latter. These results are remarkable as they run counter to the view that foreign banks, using cheap funding from abroad, have been 'pushing' FX loans into the hands of unsuspecting retail borrowers.

We further find that long-term macroeconomic stability (past inflation/trend appreciation and EU accession) rather than contemporaneous monetary conditions are associated with persistently high shares of FX lending by both domestic and foreign banks. Indirectly, the macroeconomic environment may play an important role as well. We find that between countries - but not so much within countries - a higher proportion of FX deposits is linked to higher proportions of FX lending, in particular to households. As shown by De Nicolo et al. (2005) the macroeconomic environment is a key driver of deposit dollarization.

\subsection{Foreign ownership and changes in banks' FX lending over time}

It is difficult to establish a causal relationship between bank ownership or funding and FX lending from our cross-sectional results alone. First, the observed impact of customer funding may be driven by omitted bank characteristics, for example customers with income in FX, which affect both FX deposits and FX lending. Second, the observed impact of (long-term) macroeconomic instability may be driven by unobserved country characteristics, for example institutional weaknesses which may be correlated with both weak macroeconomic policies and the absence of (exporting) firms which demand FX loans. Third, the observed relation between foreign bank ownership and FX lending to corporate clients may be due to reverse causality. Foreign banks may be more likely to enter countries where there are more clients with a demand for financial services in foreign currency, that is, countries with more export-oriented firms or a real estate market that is denominated in euro. Foreign institutions may also be more likely to take over domestic banks that already have a clientele that use financial services in foreign currency. ${ }^{8}$ In this section, we try to

\footnotetext{
${ }^{8}$ For foreign banks like ABN Amro, Bank Austria and Raiffeisen, serving foreign firms - in particular home-country clients has been an important part of their expansion strategy into emerging Europe (De Haas and Naaborg, 2006).
} 
Table 5. Foreign ownership and changes in FX lending (2001-2004)

\begin{tabular}{|c|c|c|c|c|c|c|c|c|}
\hline \multirow{3}{*}{$\begin{array}{l}\text { Dependent } \\
\text { variable }\end{array}$} & \multicolumn{4}{|c|}{ FX share (2004 minus 2001) } & \multicolumn{4}{|c|}{ FX growth } \\
\hline & \multicolumn{2}{|c|}{ Corporates } & \multicolumn{2}{|c|}{ Households } & \multicolumn{2}{|c|}{ Corporates } & \multicolumn{2}{|c|}{ Households } \\
\hline & (1) & (2) & (3) & (4) & (5) & (6) & (7) & (8) \\
\hline Foreign held & $\begin{array}{l}5.065 \\
{[5.389]}\end{array}$ & $\begin{array}{c}9.8 \\
{[6.017]}\end{array}$ & $\begin{array}{c}2.596 \\
{[5.834]}\end{array}$ & $\begin{array}{c}0.325 \\
{[6.779]}\end{array}$ & $\begin{array}{c}14.82 \\
{[14.96]}\end{array}$ & $\begin{array}{c}12.88 \\
{[12.80]}\end{array}$ & $\begin{array}{l}1.128 \\
{[1.455]}\end{array}$ & $\begin{array}{c}1.087 \\
{[1.538]}\end{array}$ \\
\hline \multicolumn{9}{|c|}{ Bank-level changes 2004-2001: } \\
\hline Assets & & $\begin{array}{c}0.503 \\
{[2.822]}\end{array}$ & & $\begin{array}{c}3.744 \\
{[11.53]}\end{array}$ & & & & \\
\hline $\begin{array}{l}\text { Wholesale } \\
\text { funding }\end{array}$ & & $\begin{array}{l}0.0081 \\
{[0.111]}\end{array}$ & & $\begin{array}{c}0.238 \\
{[0.272]}\end{array}$ & & $\begin{array}{c}0.208 \\
{[0.192]}\end{array}$ & & $\begin{array}{l}-0.0167 \\
{[0.0257]}\end{array}$ \\
\hline FX deposits & & $\begin{array}{c}-0.0494 \\
{[0.152]}\end{array}$ & & $\begin{array}{c}0.383 \\
{[0.253]}\end{array}$ & & $\begin{array}{c}0.063 \\
{[0.108]}\end{array}$ & & $\begin{array}{c}0.0409 \\
{[0.0355]}\end{array}$ \\
\hline Method & OLS & OLS & OLS & OLS & OLS & OLS & OLS & OLS \\
\hline $\begin{array}{l}\text { Country-fixed } \\
\text { effects }\end{array}$ & Yes & Yes & Yes & Yes & Yes & Yes & Yes & Yes \\
\hline$R^{2}$ & 0.23 & 0.37 & 0.39 & 0.45 & 0.22 & 0.27 & 0.37 & 0.44 \\
\hline No. of banks & 135 & 106 & 126 & 99 & 102 & 96 & 62 & 58 \\
\hline No. of countries & 20 & 20 & 20 & 20 & 20 & 20 & 14 & 14 \\
\hline
\end{tabular}

Notes: In this table we examine the sample of banks that were either domestically owned or foreign owned during the entire period 2000-2004 and which report data on FX lending for 2001 and 2004. The dependent variables are the percentage point changes (2004 minus 2001) in either the share of FX lending (Columns 1-4) or in the amount of FX lending (Columns 5-8). All models report OLS estimates with country fixed effects. Standard errors are reported in brackets and are adjusted for clustering at the country level.

***, **, * denote significance at the $0.01,0.05$ and 0.10 level.

Table 2 provides definitions and sources of all variables.

mitigate concerns about omitted variables and reverse causality by looking at changes in banks' FX lending between 2001 and 2004, controlling for time-invariant bank characteristics and changes in the macroeconomic environment.

In Table 5 we control for omitted bank-level variables by running first-difference regressions using a sub-sample of banks that did not change their ownership during 2000-2004. We examine changes in the share and the volume of FX lending between 2001 and 2004. The dependent variables in the left-hand side panel are the percentage-point change in FX share corporate/ households between 2001 and $2004 .{ }^{9}$ The dependent variables in the right-hand side panel are $F X$ growth corporates/ households, that is, the percentage-point change in the volume of FX lending to these clients. Likewise all independent variables - with the obvious exception of the Foreign held dummy - are expressed in changes as well. We control for changes in country specific monetary conditions with country fixed effects. The results presented in Table 5 suggest that foreign bank ownership did not impact the change in either the share or the volume of FX lending to firms or households.

\footnotetext{
9 A number of banks change their proportion of FX lending very considerably between 2001 and 2004 . We undertook a robustness test where we exclude extreme values in the dependent variables by trimming at the 5th and 95th percentile. This does not change our results.
} 


\subsection{Foreign acquisition and changes in banks' FX lending over time}

In Table 6 we control for reverse causality in the observed relationship between foreign bank ownership and FX lending by analysing whether the currency composition of bank lending changes when a domestic bank is taken over by a foreign strategic investor. As in Table 5, the dependent variables are the percentage-point change in FX share corporates/households (left-hand side) and FX growth corporate/ households (right-hand side). To measure the impact of foreign acquisition we limit our sample to those banks which were domestically owned before 2000 and compare banks that remained domestically owned over 2000-2004 to those that were taken over by a foreign bank in 2000, 2001 or 2002. The latter are captured by the dummy Foreign acquired. ${ }^{10}$

The results presented in Panel A of Table 6 suggest that there is no effect of foreign acquisition on FX lending to corporates. The coefficients for Foreign acquired in Columns 1-2 and 5-6 suggest that neither the share of bank lending in FX nor the growth of the FX loan volume to corporate clients differs between acquired and non-acquired banks.

The foreign acquisition of a domestic bank does, by contrast, impact FX lending to households. The results in Columns 7-8 suggest that after a take-over, acquired banks expand the volume of FX lending to households by almost 10 percentage points more than banks that remain in domestic hands. Interestingly though, the stronger increase in FX loan volume to households does not appear to be driven by an increase in the share of household loans extended in FX. The results displayed in Columns 3-4 suggest that foreign acquisition has no impact on $F X$ share households. These results suggest that the main effect of foreign acquisition is to accelerate the growth of household lending by banks. This leads to a faster growth of FX loans to households, even though the share of FX loans in the household loan portfolio does not increase.

A concern with our analysis in Panel A of Table 6 is selection bias. Foreign institutions choose to take over particular domestic banks. If our regressions omit indicators which are relevant for the takeover decision, and these indicators are positively correlated with initial FX lending, then we may underestimate the impact of foreign acquisition on the subsequent change in FX lending. In Table 6B we therefore report a propensity scoring exercise in which we attempt to mitigate potential selection bias by comparing banks that were taken over by a foreign bank with similar banks that were not taken over (Rosenbaum and Rubin, 1983). ${ }^{11}$

\footnotetext{
10 Our definition of Foreign acquired implies that after a takeover in 2000, 2001 or 2002 there are four, three and two years, respectively, during which the integration into a multinational group may have influenced the FX lending of these banks. This should be enough time to pick up an effect of foreign ownership as the parent bank may in principle start providing its new subsidiary with intrabank funding as soon as the takeover is finalized.

11 See Havrylchyk and Jurzyk (2010) for a similar application to investigate the impact of foreign bank ownership on the performance and market power of acquired banks.
} 
Table 6. Foreign acquisition and changes in FX lending (2001-2004)

Panel A. OLS regressions

\begin{tabular}{|c|c|c|c|c|c|c|c|c|}
\hline \multirow{3}{*}{$\begin{array}{l}\text { Dependent } \\
\text { variable }\end{array}$} & \multicolumn{4}{|c|}{ FX share (2004 minus 2001) } & \multicolumn{4}{|c|}{ FX growth } \\
\hline & \multicolumn{2}{|c|}{ Corporates } & \multicolumn{2}{|c|}{ Households } & \multicolumn{2}{|c|}{ Corporates } & \multicolumn{2}{|c|}{ Households } \\
\hline & (1) & (2) & (3) & (4) & $(5)$ & (6) & (7) & (8) \\
\hline Foreign acquired & $\begin{array}{l}-4.859 \\
{[4.759]}\end{array}$ & $\begin{array}{l}-5.388 \\
{[7.663]}\end{array}$ & $\begin{array}{c}2.229 \\
{[5.005]}\end{array}$ & $\begin{array}{l}-0.577 \\
{[8.352]}\end{array}$ & $\begin{array}{c}1.046 \\
{[2.001]}\end{array}$ & $\begin{array}{c}1.926 \\
{[2.305]}\end{array}$ & $\begin{array}{l}8.724 * * \\
{[3.789]}\end{array}$ & $\begin{array}{l}9.831 * * \\
{[3.804]}\end{array}$ \\
\hline \multicolumn{9}{|c|}{ Bank-level changes 2004-2001: } \\
\hline Assets & & $\begin{array}{l}-2.155 \\
{[3.479]}\end{array}$ & & $\begin{array}{l}-3.571 \\
{[7.537]}\end{array}$ & & & & \\
\hline Wholesale funding & & $\begin{array}{c}0.151 \\
{[0.175]}\end{array}$ & & $\begin{array}{c}0.195 \\
{[0.271]}\end{array}$ & & $\begin{array}{c}-0.00955 \\
{[0.0651]}\end{array}$ & & $\begin{array}{l}-0.0565 \\
{[0.0609}\end{array}$ \\
\hline FX deposits & & $\begin{array}{c}-0.0253 \\
{[0.239]}\end{array}$ & & $\begin{array}{c}0.13 \\
{[0.134]}\end{array}$ & & $\begin{array}{c}-0.0533 * * \\
{[0.0237]}\end{array}$ & & $\begin{array}{c}0.0702^{*} \\
{[0.0339}\end{array}$ \\
\hline Method & OLS & OLS & OLS & OLS & OLS & OLS & OLS & OLS \\
\hline Country-fixed effects & Yes & Yes & Yes & Yes & Yes & Yes & Yes & Yes \\
\hline$R^{2}$ & 0.21 & 0.32 & 0.42 & 0.52 & 0.19 & 0.28 & 0.44 & 0.75 \\
\hline No. of banks & 117 & 89 & 115 & 87 & 90 & 82 & 60 & 54 \\
\hline No. of countries & 18 & 18 & 18 & 18 & 18 & 18 & 14 & 14 \\
\hline
\end{tabular}

Notes: In this panel we compare the change in FX lending (2004 minus 2001) by domestic banks which were acquired in 2000, 2001 or 2002 to the change in FX lending by domestic banks that were not acquired. The dependent variables are percentage point changes in the share of FX lending (Columns 1-4) or the growth (2004 minus 2001) of FX volume in \% (Columns 5-8). All models report OLS estimates with country-fixed effects. Standard errors are reported in brackets and are adjusted for clustering at the country level.

***, **, * denote significance at the $0.01,0.05$ and 0.10 level.

Table 2 provides definitions and sources of all variables.

Panel B. Controlling for endogenous acquisition - Propensity score matching

\begin{tabular}{|c|c|c|c|c|c|c|}
\hline & & Acquired & Not acquired & Difference & S.E. & $t$-stat \\
\hline \multicolumn{7}{|c|}{ FX share (2004 minus 2001) } \\
\hline \multirow[t]{3}{*}{ Corporates } & Unmatched & 2.82 & 4.91 & -2.09 & 5.29 & -0.39 \\
\hline & Nearest neighbour matching & 2.28 & 8.37 & -6.09 & 9.78 & -0.62 \\
\hline & Kernel matching & 5.84 & 5.83 & 0.01 & 6.99 & 0.00 \\
\hline \multirow[t]{3}{*}{ Households } & Unmatched & 2.52 & 1.83 & 0.69 & 6.23 & 0.11 \\
\hline & Nearest neighbour matching & 3.02 & 5.71 & -2.69 & 8.41 & -0.32 \\
\hline & Kernel matching & 0.64 & 8.70 & -8.06 & 9.46 & -0.85 \\
\hline \multicolumn{7}{|l|}{$F X$ growth } \\
\hline \multirow[t]{3}{*}{ Corporates } & Unmatched & 4.96 & 3.71 & 1.25 & 1.51 & 0.83 \\
\hline & Nearest neighbour matching & 4.09 & 2.76 & 1.33 & 1.68 & 0.79 \\
\hline & Kernel matching & 5.63 & 3.69 & 1.95 & 2.16 & 0.9 \\
\hline \multirow[t]{3}{*}{ Households } & Unmatched & 9.64 & 3.29 & 6.35 & 2.14 & $2.96 * * *$ \\
\hline & Nearest neighbour matching & 9.64 & 3.38 & 6.26 & 3.23 & $1.94 * *$ \\
\hline & Kernel matching & 9.64 & 3.39 & 6.25 & 3.22 & $1.94 * *$ \\
\hline
\end{tabular}

Notes: In this panel we compare the change in FX lending (2004 minus 2001) by domestic banks which were acquired in 2000, 2001 or 2002 to the change in FX lending by domestic banks that were not acquired. The propensity to be acquired is estimated as a function of the banks Asset volume ( $\log$ USD, in 2000) and a set of country dummies. The table reports treatment effects based on unmatched comparisons as well as nearest neigbour matching (with a common support requirement) and kernel matching. ***, ** denote significance at the 0.01 and 0.05-level. 
In a first step we run a probit regression on the sub-sample of domestic banks in 2000 in which the dependent variable is Foreign acquired. This probit regression yields a propensity score (the conditional probability of a bank being acquired given pre-acquisition characteristics) for each bank. As explanatory variables in the firststep regression we include bank size and country-fixed effects. We expect that acquiring banks are mainly interested in large banks, as they search for a minimum presence and scale in a country. The first-stage probit regression results (available upon request from the authors) show that bank size is indeed an important determinant of the acquisition probability. In addition, various country-fixed effects are significant, indicating that foreign strategic investors targeted particular countries more than others, for instance because of a higher credit-growth potential and a better institutional environment.

In a second step we match each 'treated' (acquired) bank to similar banks that were not acquired by a strategic investor. We either match an acquired bank to the closest propensity score (nearest neighbour match with a common-support requirement) or use Gaussian kernel matching. ${ }^{12}$ The results in Table $6 \mathrm{~B}$ confirm our finding of Table 6A that over the 2001-2004 period acquired banks expanded their FX loan volume (but not their FX loan share) to households significantly faster than banks that remained in domestic hands. Again, we find no relation between foreign acquisition and changes in FX lending to corporate clients.

\subsection{Convergence of FX lending within countries and multinational banks}

In this section we examine the role of foreign banks in spreading FX lending within countries (to domestic banks). We also examine their role in spreading FX lending across countries through their multinational networks. Panel A of Table 7 displays the results for within-country and Panel B for within-network dispersion of FX lending.

Panel A reports regressions on our sample of banks for which information on FX lending is available for 2001 and 2004. We relate the change in FX share corporate/ households over the 2001-2004 period to the dummy variable Low FX 2001 in country which is 1 if in 2001 a bank had a lower proportion of FX lending compared to the country average. As in Tables 5 and 6 we control for cross-country variation in changes in macroeconomic conditions through country fixed-effects.

The results provide evidence for convergence of FX lending within countries. Banks with below-average levels of FX lending in 2001 increased the share of FX loans the fastest between 2001 and 2004. A bank that had below-average FX lending in 2001 subsequently increased its proportion of FX lending to firms and

\footnotetext{
${ }^{12}$ In the latter case the counterfactual outcome is calculated as a kernel-weighted average of the outcomes of all nonacquired banks. Weights are inversely proportional to the distance between the propensity scores of acquired and nonacquired banks.
} 


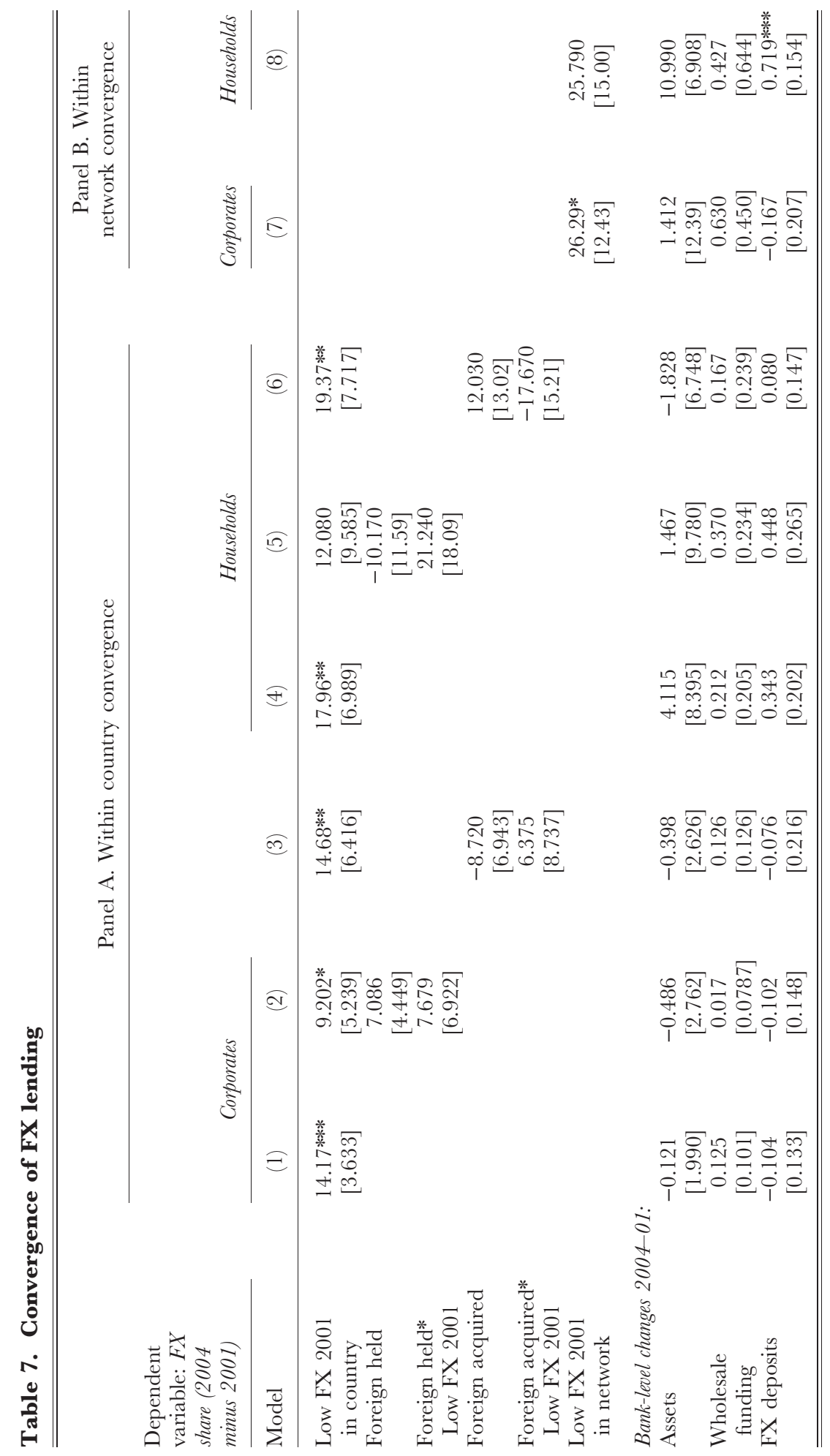


84

MARTIN BROWN AND RALPH DE HAAS

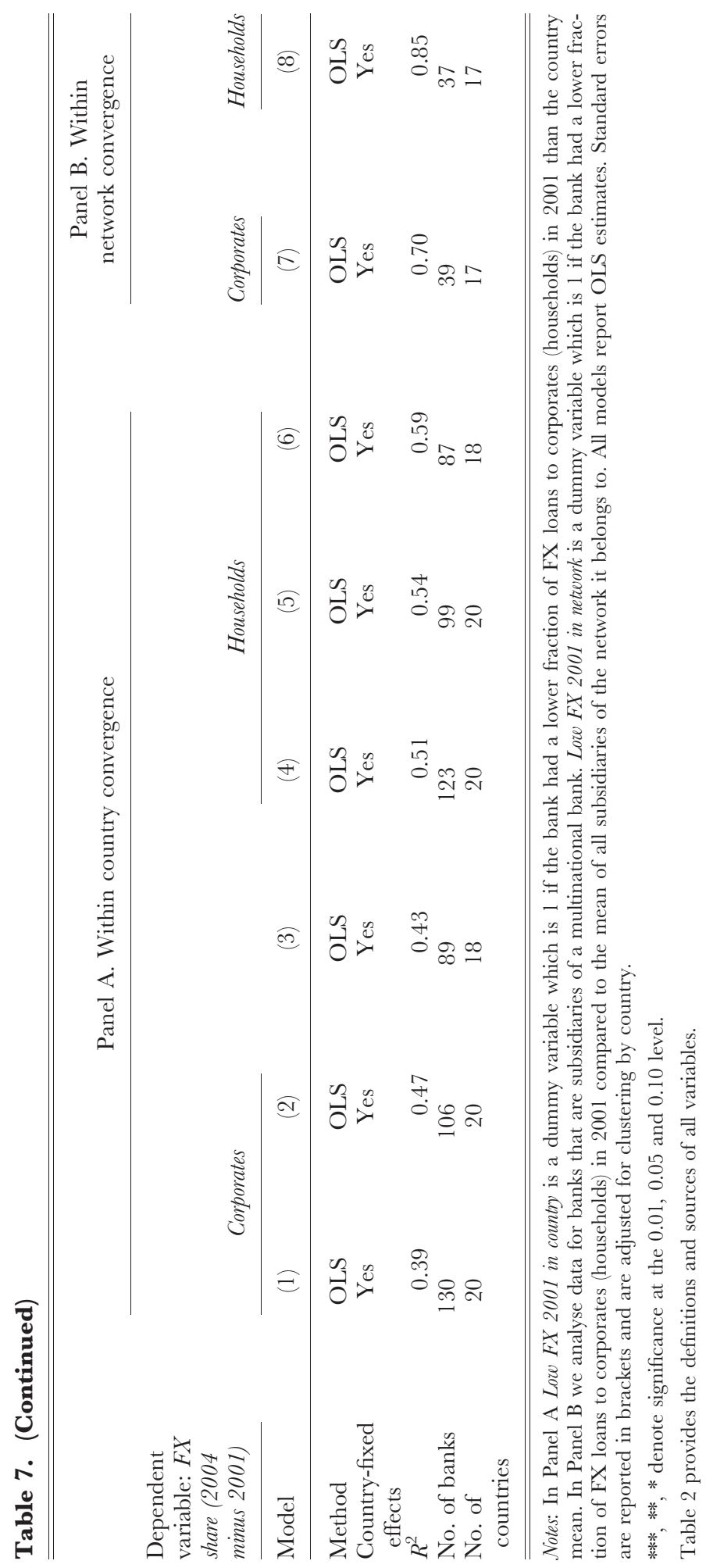


households by $14 \%$ and $18 \%$ more, respectively, compared to banks in the same country that had above average shares of FX loans in 2001.

Király et al. (2009) point out that in the case of Hungary the combination of foreign-bank ownership and intense inter-bank competition was a key determinant of FX lending. Did foreign banks start the euroization process while intense competition merely forced domestic banks to follow their foreign competitors? We find no evidence that the catching up effect identified above is driven in particular by domestic or foreign banks. In Columns 2, 3, 5 and 6 we examine whether foreign banks spread FX lending to domestic banks during our observation period. We interact the variable Low FX 2001 in country with a Foreign held dummy, which is one for banks that were already foreign owned in 2000, or a Foreign acquired dummy, which is one for banks that became foreign owned in 2000, 2001 or 2002. The results are in line with banking competition increasing FX lending as a two-way rather than as a unidirectional process.

In Panel B of Table 7 we examine whether foreign banks spread FX lending across countries through their multinational networks. For this exercise we analyse a sub-sample of banks which belong to a multinational banking group - such as UniCredit Group, Raiffeisen International or Société Générale - for which we have at least three subsidiaries from the group in our sample. We relate changes in $F X$ share corporates/households between 2001 and 2004 to a dummy variable Low FX 2001 within network which is 1 for subsidiaries with a proportion of FX lending below the 2001 average for the group they belong to. As in Panel A we find positive coefficients for the variable Low FX 2001 although the estimates are not precisely estimated. We cannot conclude that during our observation period multinational banking groups used their internal capital markets to spread FX lending throughout their network.

\section{CONCLUSIONS AND POLICY IMPLICATIONS}

We use a unique dataset - containing detailed information on the loan and deposit structure of nearly 200 banks in 20 transition economies - to examine how FX lending is related to bank ownership, bank funding and the macroeconomic environment. We focus on the extent to which foreign-owned banks and wholesale funding have contributed to the widespread use of FX lending in emerging Europe.

Overall our results contradict the view that foreign-owned banks have been driving FX lending to unsuspecting retail clients throughout Eastern Europe as a result of easier access to cross-border wholesale funding. First, our cross-sectional results suggest that while foreign banks do lend more in FX to corporate clients, they do not do so to retail clients. Second, while foreign acquisition of a bank does lead to faster growth in FX lending to households, this is driven by faster growth in household lending per se, and not be a redirecting of household credit from domestic to foreign currency. Third, we find no evidence that wholesale funding had a strong causal effect on FX lending 
for any type of bank over the 2001-2004 period. The correlation between wholesale funding and FX lending at the bank level is weak, and if anything wholesale funding seems to be a result rather than a determinant of FX lending.

Our results also contradict the view that foreign bank presence spread the FX lending to domestic banks in emerging Europe. We do find evidence for a within-country convergence process of FX lending. However, we show that both foreign and domestic banks with low levels of FX lending in 2001 - compared to the country average - let their FX lending increase faster over the subsequent three years. Finally, at the country level, our results suggest that banks' FX lending is driven by long-term macroeconomic stability rather than contemporaneous monetary conditions. In particular, a history of high inflation and prospective EU accession are associated with high levels of euroization. Again, this holds for both domestic and foreign banks.

All in all, our findings tell us that foreign banks did not indiscriminately 'push' FX loans through their subsidiary network in the transition region, but followed a more cautionary approach where FX lending is targeted to (corporate) clients that can carry the associated risks and to countries in which FX lending to households is attractive from a macroeconomic and institutional perspective. Our results provide important insights to policymakers into the drivers of FX lending in Eastern Europe. They show that FX customer deposits rather than wholesale funding have been a key driver of FX lending in the region. This suggests that credible macroeconomic policies which encourage customers to save in local currency may in many countries be more important than regulatory proposals to limit the wholesale funding of (foreign) banks.

Indeed, countries like the Czech Republic and Poland demonstrate how adherence to credible macroeconomic policies can result in relatively low levels of FX lending even when a majority of the banking system is foreign owned. Similarly, various Latin American countries have successfully de-dollarized by moving to macroeconomic regimes that were more conducive to local currency funding, including flexible exchange rate regimes and inflation targeting (see Zettelmeyer et al., 2010). Having said that, our results also indicate that macroeconomic stabilization within the framework of a credible political commitment to eventual euro adoption, may actually stimulate firms and households to disregard any residual currency risk and expand their FX borrowing.

In countries with weak monetary and fiscal institutions a strong regulatory response to reduce $\mathrm{FX}$ lending may even be counterproductive as lending in domestic currency is not a realistic alternative in the short term. In those cases, reducing FX lending through regulation may just lead to less credit. The current policies in Ukraine and Belarus, where new FX denominated mortgages (Ukraine) or all FX retail loans (Belarus) have been banned, may come at the cost of an even sharper decline in bank lending.

This is not to say that regulation can or should not play a role in reducing FX lending. In a second-best world where monetary credibility is not instantly 
attainable, regulation may be an optimal instrument, at least for some time. Regulation may well be advisable if banks and their customers create (unhedged) FX debt whilst disregarding that growing currency mismatches may increase the probability of a systemic crisis. Such behaviour may become apparent when banks count on an explicit or implicit government commitment to maintain nominal exchange rate stability (see Rancière et al., 2010) such as in the run-up to euro membership. In such cases, regulators may for instance require banks to hold unremunerated reserve requirements on their FX funding or may introduce higher capital and/or provisioning requirements for FX loans. Poland has been successful in weighing against the tide of FX lending by introducing Recommendation $\mathrm{S}$ in 2006, which required banks to apply stricter credit underwriting standards and to disclose FX risks when providing FX mortgages. Measures like these may partially restore a level playing field between FX and local currency loans and force banks and their borrowers to take the externalities of their lending decisions into account.

Finally, we should underline that our empirical analysis has focused quite narrowly on the impact of bank funding and ownership on the currency composition of credit across emerging Europe. Even though we do not find that foreign banks have had a strong influence on the share of FX lending, we do find that they have been instrumental in pushing the amount of household lending (both in local and foreign currencies). Given the underdeveloped nature of mortgage and consumer credit markets across emerging Europe this development should in principle be viewed positively, as it has allowed households to better smooth consumption over time. Yet, previous crises in emerging markets as well as developed countries have shown that episodes of rapid financial deepening may turn into self-fulfilling and unsustainable credit booms. Indeed, many countries in Emerging Europe - including the Baltic States, Ukraine and Kazakhstan - are still recovering from burst credit and real estate bubbles. To the extent that foreign banks played a particular role in financing these bubbles - again, regardless of the currency of denomination of this financing - they may still have contributed to financial instability. We leave this issue, as well as the role that access to finance has played in shaping households' ability to cope with the crisis, for future research.

\section{Discussion}

\section{Cédric Tille}

\section{Graduate Institute of International and Development Studies, Geneva and CEPR}

The reliance on loans denominated in foreign currencies has long been a highly relevant question for emerging market economies. Such financing has a clear appeal from the borrower's point of view in the form of a lower interest rate, reflecting the fact that the lender does not bear the exchange rate risk. This advantage comes at 
the cost of magnifying the impact of exchange rate crisis. A sharp fall in the external value of the emerging economy's currency raises the debt burden in terms of local currency, which can push the borrower into insolvency. This drawback of foreign currency borrowing played a central role in the emerging market crises of the 1990s, as well as in the current crisis where borrowers in emerging Europe, which had accumulated a substantial debt in foreign currency, saw the local-currency value of their debt surge.

The rise in foreign currency debt in Eastern Europe took place at a time when foreign banks increased their presence in these markets either by setting up branches or buying local banks. This has led to criticism that foreign currency debt, and its cost, was 'pushed' by foreign banks on local borrowers. The paper rigorously assesses this claim relying on detailed data on the balance sheet of banks in emerging Europe in the early 1990s. The authors clearly refute the thesis of an undiscriminating push of foreign currency loans. While foreign banks did issue a substantial amount of such loans, they did so to a similar extent as domestic banks. Furthermore, loans were not granted blindly, but instead reflected macroeconomic fundamentals, with more foreign currency lending in countries where inflation was more volatile. The policy inference is thus that efforts at limiting the reliance on foreign currency borrowing should not single-out foreign banks.

\section{The early and late stages of the lending boom}

While the BEPS data provide a highly detailed view of banks' lending activity, they only cover the first half of the 2000s. The first part of the decade clearly saw a substantial increase in bank lending to emerging Europe, but this was dwarfed by the surge between 2004 and the eve of the crisis. Figure 3 shows the claims of BIS-reporting banks on emerging Europe on a consolidated basis. We clearly observe that the volume of claims quadrupled between March 2005 and March 2008, both in terms of cross-border lending and in terms of lending through local affiliates.

The authors fully acknowledge this limitation of their data, and point out that the subsequent boom does not make the initial period less informative, as it sets the stage for the subsequent episode. In Table Al they show that many countries saw the share of foreign currency lending increase before the mid-2000s. The period covered by the paper does indeed lead to interesting insight, and is the only data so far available on such a disaggregated basis.

The inferences, however, still have to be taken with some caution in terms of their applicability to the subsequent developments. First, not all countries saw an increase in lending in the initial years, as shown in Figure 4 which shows the data from Table Al for selected countries. Estonia clearly experienced a shift toward foreign currency lending in the first half of the decade, which persisted in the second half. The situation is more contrasted for other countries such as Latvia, however, 


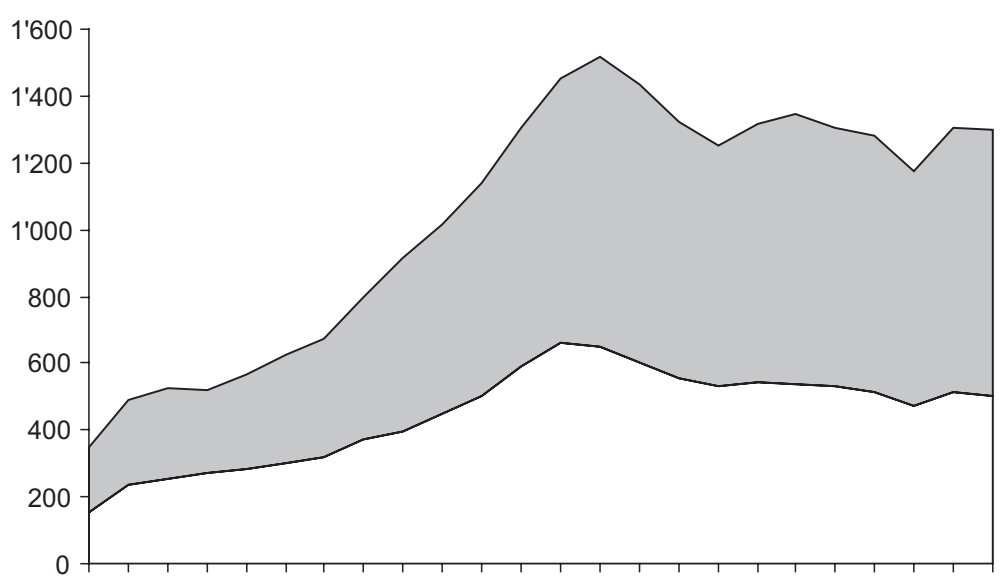

March 2005 March 2006 March 2007 March 2008 March 2009 March 2010

$\square$ Cross-border lending $\square$ Local affiliates lending

Figure 3. BIS reporting banks' exposure to emerging Europe (consolidated basis, US\$ billions)

Source: Bank for International Settlements (BIS).

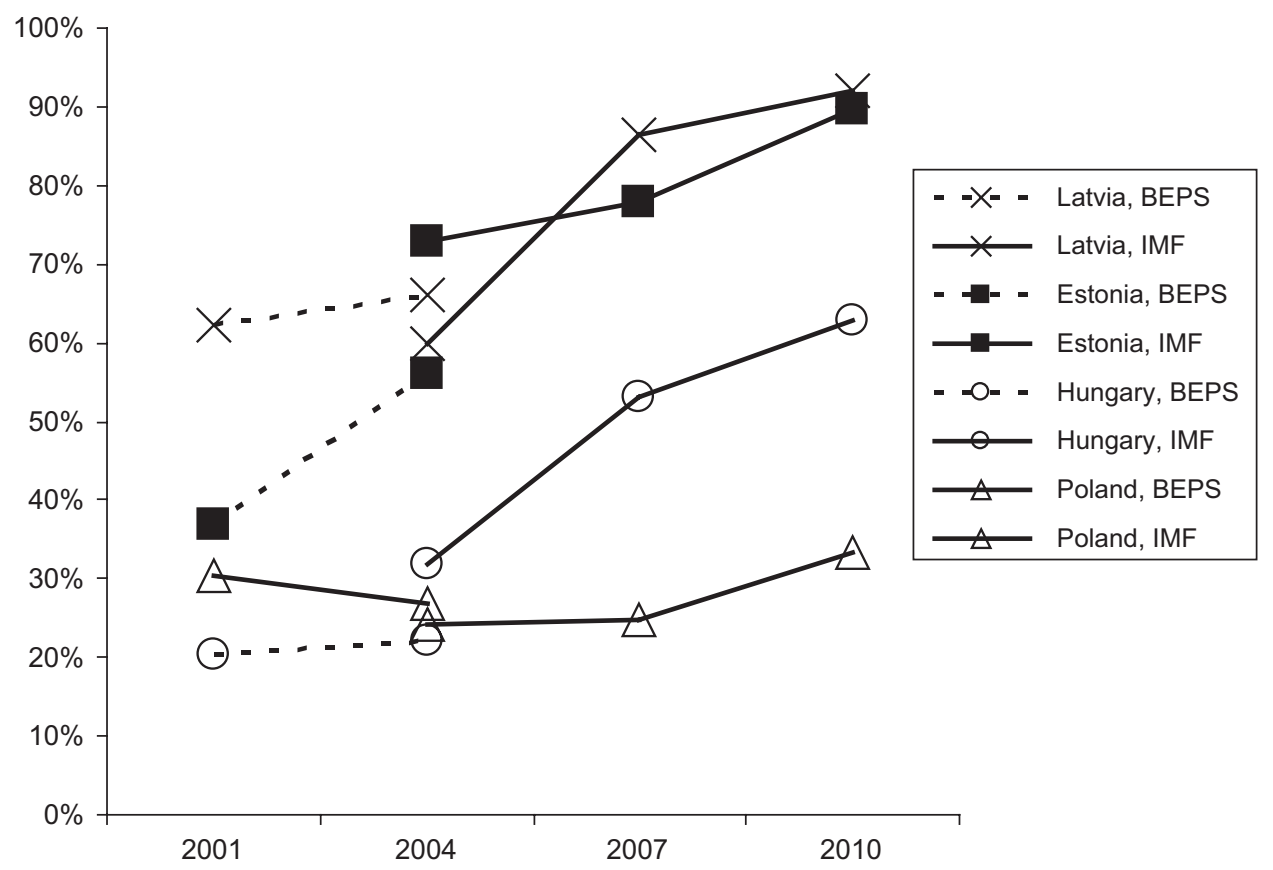

Figure 4. Share of foreign currency loans, selected countries

Notes: The dotted lines show BEPS data and the solid line IMF data.

Sources: Table A1. 
where the initial increase in the share was much less pronounced than for other countries. In addition, some of the largest countries in the region saw little increase in the share prior to 2004. This is the case for Poland, where the foreign currency lending share only increased in the crisis, and fairly moderately, as well as for Hungary where the boom in foreign currency lending appears concentrated on the eve of the crisis, between 2004 and 2007. The case of Hungary is especially noteworthy as it is one of the countries where the reliance of households on foreign currency loans has been the object of extensive policy discussion.

A second reason for caution is that the evidence in Table Al only pertains to aggregate trends for foreign banks. It thus does not inform us on whether these trends differed relative to domestic banks, or whether the connection between economic fundamentals and foreign currency lending loosened. Of course this caveat does not reduce the relevance of studying the lending pattern in the early years, but merely points to some caution in extending the inferences to subsequent years.

\section{Foreign currency or foreign banks?}

The criticism of reliance on foreign banks does not solely link to their issuing foreign currency loans, but also relates to the risk that they could quickly pull back from the marginal markets that emerging countries represent, whereas local banks would be more inclined to sustain their lending (Cetorelli and Goldberg, 2011, however argue that this is not the case).

These two aspects (foreign currency lending, or volatile lending) are often confused in the discussion on foreign banks. It is, however, important to distinguish them as they have different policy implications. If foreign currency lending is the problem, then policymakers should explicitly restrict its use for all banks, regardless of foreign or domestic ownership, for instance by putting in place strict collateral requirements. If on the other hand reliance on foreign banks entails the risk of depending on 'footloose' funding, then international financial integration should be sequenced and make more use of more stable sources of funding, such as foreign direct investment.

\section{An impact of foreign banks through competition?}

The central finding of the paper is that foreign banks did not push foreign currency lending, in the sense that the increase in foreign currency lending is not correlated with the ownership of the bank.

Yet, the pattern of a broad-based issuance of foreign currency debt can be consistent with a causal role of foreign banks. Consider a situation where domestic banks are initially reluctant to issue foreign currency loans. The economy then experiences a substantial entry of foreign banks in the markets, which are keener on issuing foreign currency debt. As these loans carry a lower interest rate, they are 
attractive for borrowers despite the implied exposure to currency risk. Faced with this development, domestic banks can stick to their focus on local currency lending, but will then likely loose market share. They can instead follow the lead of foreign banks and also issue foreign currency debt. In such a scenario, we would observe an increase in foreign currency lending for both foreign and domestic banks, even though the development is triggered by foreign banks by assumption. While domestic banks will move into foreign currency debt with some delay, this timing is unlikely to be apparent in infrequent surveys, and capturing it would require more frequent data.

One thus cannot exclude that domestic banks merely reacted to a development induced by foreign banks. While the paper does not explicitly address this issue, it shows that domestic banks did not increase their foreign currency debt to corporate customers, even though the competitive pressure from foreign banks was also likely to be present there. This element is indicative that the rise in foreign currency lending was not solely pushed by foreign banks. It remains nonetheless that future research should assess the possibility of an indirect impact of foreign banks through competitive pressures on domestic ones.

\section{Conclusion}

The paper shows that the rise in foreign currency lending in emerging Europe cannot be squarely attributed to a push by foreign banks. If policymakers want to reduce the reliance of borrowers on such loans, they should then explicitly do so and not attempt to achieve the objective indirectly by targeting foreign banks.

An interesting avenue for future work is to extend the analysis in two main directions. First, one should assess whether the patterns documented in the paper apply to the lending boom in the second half of the 2000s, a period not covered by the paper. In particular, it will be interesting to assess whether banks facing very low returns in their mature domestic markets ventured more forcefully into emerging countries than they did in the first part of the decade. Second, one should consider whether the issuance of foreign currency loans by local banks solely reflects macroeconomic conditions, or whether it is an indirect consequence of the entrance of foreign banks and the competitive pressures on incumbents that it entails.

\section{László Halpern IEHAS and CEPR}

The paper adresses a very timely issue - what is the foreign currency exposure in transition economies and to what extent is it driven by foreign banks. As the large credit boom experienced in these countries was partly made in foreign currencies 
and when capital flows reversed and exchange rates came under pressure this high - mostly unhedged - foreign currency exposure became a serious problem for corporations and households. The data used in this paper are unique as there are two observations - 2001 and 2004 - for individual bank level indicators for transition economies. The central result of the paper, that is, the rejection of the popular claim that foreign banks are to be blamed for the high foreign currency exposure rightly vindicates the attention of analysts and policymakers, too. My main concern is, however, that the results are not interpreted with due caution; data, their use and the way the results were obtained raise quite a few questions.

There are four countries - Albania, Hungary, Kazakhstan and the Slovak Republic - for which either domestic or foreign banks are missing from the sample. In their case it is impossible to compare the behaviour of foreign and domestic banks. It would have been more appropriate to leave out these countries from the whole exercise.

Authors claim that that the period 2001-2004 - that is, the first half of the 2001-2007 credit boom in many parts of emerging Europe - is well suited to study the determinants of FX lending as it set the scene for later developments. This claim, however, seems to go beyond the validity of the analysis especially in light of the changing behaviour of banks, households and corporations during the second half of the credit boom presented in different EBRD reports. ${ }^{13}$ As documented in Table A1, in the case of half of the countries the share of FX lending rose between 2007 and 2010. But only two of them - Hungary and Latvia - showed that the growth pattern was more or less similar in the two consecutive subperiods between 2004 and 2010, namely in the case of the other countries there was no growth in the share between 2004 and 2007 on the basis of the IMF data.

Currency composition within foreign currencies should have mattered. As monetary integration with the euro was on the agenda of quite a few countries in the sample it is relevant what the currency of lending was in these cases. The euro is a quite natural choice for a medium to long-term credit transaction with a perspective of monetary integration on the horizon, while the massive lending in Swiss francs and Japanese yen certainly require additional explanation. Lending in noneuro, however, was not specific to the countries investigated, as there was massive lending in Swiss francs in Austria, for example.

The interpretation of the wholesale funding - what captures non-customer liabilities as a share of total liabilities - as an indicator of wholesale funding in foreign currency does not reflect the heterogeneity of countries in the sample. Although the assumption as much of the transition region remains characterized by very underdeveloped local currency bond and money markets is acceptable but the difference between countries seems to be even larger than in the case of developed countries.

\footnotetext{
${ }^{13}$ EBRD Transition Report 2010 presents in details how the evolution of FX lending was different after 2004 as compared to the pre-2004 period by countries and within countries by households and corporations.
} 
Obviously this heterogeneity can be captured by the country dummies, but the interpretation of the variable remains unresolved.

The instrument for wholesale funding is the dummy variable internal ratings, which indicates whether the bank used an internal ratings based approach in 2004. However, it is not clear whether banks relying on internal ratings differentiated between corporate and household clients or, put differently, whether this variable is able to capture the eventual rating difference between corporate and household clients within the bank.

My general concern with respect to the results and conclusions comes from the lack of robust results; looking at Columns 5 and 10 in Table 4 when country-fixed effects are included, the significance of foreign ownership and FX deposit vanishes. It means that when country features are taken into account the key findings are not supported with sufficient precision.

The claim that the result is mainly driven by between-country variation in FX deposits rather than between-bank variation in access to FX deposits within countries would be acceptable if the between-banks variation is properly accounted for. Foreign banks belong to groups who operate in different countries mostly. These banks may reveal different patterns of foreign lending beyond the properties - member of a multinational bank network, loan size, share of real-estate loans - examined in the paper. These additional features could have been captured by the country of origin or by the individual multinational bank networks dummies.

The paper mentions the example of the Czech Republic and Poland, demonstrating how adherence to credible macroeconomic policies can result in relatively low levels of FX lending even when a majority of the banking system is foreign owned. The other appraisal relates to Poland being successful in weighing against the tide of FX lending by introducing Recommendation S in 2006, which required banks to apply stricter credit underwriting standards and to disclose FX risks when providing FX mortgages. The results do not help to discriminate between the above two possibilities, that is, to what extent sound macroeconomic fundamentals or macroprudential policies and supervisory regulation can result in low FX exposure.

\section{Panel discussion}

Nicola Fuchs-Schündeln opened the discussion and suggested the authors should provide a more detailed analysis of the determinants of the increase in foreign lending to households. She urged the authors to consider other macro-level variables which may play an important role in foreign lending to households. She highlighted the similarities in the development of lending in both sectors over the period and noted that some determinants in the model are found to have similar effects. She also urged the authors to draw on the related theoretical literature to provide the 
motivation for distinguishing between lending to households and corporate sectors in their analysis.

Michael Haliassos suggested that the average duration and size of the loans were two important characteristics that should be controlled for in the model. He thought it was unlikely that households would consider drawing down small loans in a foreign currency. He wondered about the role of household financial knowledge on the demand for foreign currency loans. He was unsure whether greater individual financial knowledge meant individuals were more or less inclined to borrow in foreign currency or listen to the advice of banks.

Georges de Ménil believed the paper raised very important questions on whether policymakers should be concerned about the risk of volatility of the source of funding of foreign banks and/or the foreign exchange nature of their funding. He argued that the presence of foreign banks is beneficial and therefore it is necessary to have appropriate policies which deal with the risks of the inherent structural change of the increased presence of foreign banks. He agreed that large FX net liabilities entail a currency risk but he wondered whether it mattered if policymakers restrict demand or supply in order to mitigate this risk. Finally, he believed it was important to emphasize that it was not just bad macroeconomic policy which led to excessive foreign lending in some Eastern European countries.

Livio Stracca agreed with the discussants that the authors should control for a country's exchange rate regime. He also suggested that the risks associated with foreign currency lending and exchange rate movements may be to some degree offset by the foreign currency deposits which are held by banks. Refet Gürkaynak added that the risk of exchange rate movements are unlikely to be offset for individuals as they are unlikely to hold both foreign assets and liabilities.

In reply to comments made by the discussants, Martin Brown did not believe it was wholesale lending which was driving $\mathrm{FX}$ in the Eastern Europe. He pointed out that the increase in FX lending was much stronger in the period 2000-2004 which was before the large increase in wholesale lending which had occurred since 2004. He noted that current policy proposals to curb wholesale lending into Eastern Europe in order to reduce FX lending and ensure financial stability are based on a supply-side interpretation of the phenomenon and this was not supported by their findings.

He accepted that the insignificant effect of contemporaneous monetary policy on FX lending appeared surprising but noted that this finding is supported by previous research which shows there is very little effect of exchange rate and interest rate changes on FX leading over time in a given country. The findings in this paper suggest that long-run macroeconomic policy variables, such as the long-run inflation rate and a country's intention to join the European Union, matter most. 


\section{APPENDIX}

Table A1. Aggregate FX lending in Emerging Europe: 2001-10

\begin{tabular}{|c|c|c|c|c|c|}
\hline \multirow{2}{*}{$\begin{array}{l}\text { Year } \\
\text { Source }\end{array}$} & \multirow{2}{*}{ 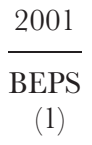 } & \multicolumn{2}{|c|}{2004} & \multirow{2}{*}{$\frac{2007}{\mathrm{IMF}}$} & \multirow{2}{*}{$\frac{2010}{\mathrm{IMF}}$} \\
\hline & & $\begin{array}{c}\text { BEPS } \\
(2 \mathrm{a})\end{array}$ & $\begin{array}{c}\mathrm{IMF} \\
(2 \mathrm{~b})\end{array}$ & & \\
\hline Albania & 0.83 & 0.80 & 0.70 & 0.71 & 0.68 \\
\hline Belarus & 0.52 & 0.71 & 0.58 & 0.64 & 0.80 \\
\hline Bosnia and Herzegovina & n.a. & n.a. & n.a. & 0.74 & 0.72 \\
\hline Bulgaria & 0.25 & 0.37 & 0.48 & 0.50 & 0.61 \\
\hline Croatia & n.a. & n.a. & n.a. & 0.60 & 0.73 \\
\hline Estonia & 0.37 & 0.56 & 0.73 & 0.78 & 0.90 \\
\hline FYR Macedonia & n.a. & n.a. & n.a. & 0.55 & 0.58 \\
\hline Hungary & 0.20 & 0.22 & 0.32 & 0.53 & 0.63 \\
\hline Kazakhstan & 0.62 & 0.51 & 0.52 & 0.43 & 0.42 \\
\hline Latvia & 0.62 & 0.66 & 0.60 & 0.86 & 0.92 \\
\hline Lithuania & 0.51 & 0.47 & 0.58 & 0.55 & 0.75 \\
\hline Moldova & 0.28 & 0.24 & 0.40 & 0.44 & 0.42 \\
\hline Poland & 0.30 & 0.27 & 0.24 & 0.25 & 0.33 \\
\hline Romania & 0.55 & 0.69 & 0.60 & 0.54 & 0.63 \\
\hline Russia & 0.38 & 0.33 & 0.26 & 0.23 & 0.22 \\
\hline Serbia & 0.35 & 0.48 & n.a. & 0.78 & 0.80 \\
\hline Slovak Republic & 0.07 & 0.09 & 0.14 & 0.16 & n.a. \\
\hline Ukraine & 0.55 & 0.59 & n.a. & 0.50 & 0.47 \\
\hline
\end{tabular}

Notes: This table provides aggregated country-level data on FX lending for the years 2001, 2004, 2007 and 2010. Data for a number of Balkan countries are not comparable across BEPS and IMF statistics due to a different treatment of FX-linked loans and therefore not shown. The Slovak Republic joined the eurozone in 2009. n.a.: not available.

Data source: BEPS, IMF Article IV reports and CEIC.

\section{Table A2. Pairwise correlations}

Panel A. Bank-level variables: 2004

\begin{tabular}{|c|c|c|c|c|c|c|c|c|}
\hline & & [1] & [2] & [3] & [4] & [5] & [6] & [7] \\
\hline [1] & FX share corporates & 1.00 & & & & & & \\
\hline [2] & FX share households & 0.60 & 1.00 & & & & & \\
\hline [3] & Assets & 0.03 & 0.01 & 1.00 & & & & \\
\hline [4] & Wholesale funding & 0.16 & 0.13 & 0.05 & 1.00 & & & \\
\hline [5] & FX deposits & 0.44 & 0.43 & -0.14 & -0.11 & 1.00 & & \\
\hline [6] & Internal ratings & -0.08 & -0.02 & 0.05 & 0.24 & -0.10 & 1.00 & \\
\hline [7] & Corporate deposits & 0.10 & 0.25 & -0.17 & 0.06 & 0.29 & -0.09 & 1.00 \\
\hline
\end{tabular}

Panel B. Bank-level variables: 2004-2001 differences

\begin{tabular}{llccccccr}
\hline & & {$[1]$} & {$[2]$} & {$[3]$} & {$[4]$} & {$[5]$} & {$[6]$} & {$[7]$} \\
\hline$[1]$ & FX share corporates & 1.00 & & & & & & \\
{$[2]$} & FX share households & 0.27 & 1.00 & & & & & \\
{$[3]$} & FX growth corporates & 0.22 & 0.30 & 1.00 & & & & \\
{$[4]$} & FX growth households & 0.00 & 0.58 & 0.29 & 1.00 & & & \\
{$[5]$} & Assets & -0.02 & 0.11 & 0.32 & 0.50 & 1.00 & & \\
{$[6]$} & Wholesale funding & 0.07 & 0.06 & 0.14 & -0.07 & 0.20 & 1.00 & \\
{$[7]$} & FX deposits & 0.09 & 0.26 & 0.03 & 0.10 & -0.03 & -0.04 & 1.00 \\
\hline
\end{tabular}


Table A2. (Continued)

Panel C. Country-level variables: 2001-2004 averages

\begin{tabular}{lcccccc}
\hline & & {$[1]$} & {$[2]$} & {$[3]$} & {$[4]$} & {$[5]$} \\
\hline$[1]$ & Interest rate differential & 1.00 & & & & \\
{$[2]$} & Exrate volatility & 0.70 & 1.00 & & & \\
{$[3]$} & Interest advantage & 0.74 & 0.20 & 1.00 & & \\
{$[4]$} & Inflation history & 0.63 & 0.63 & 0.22 & 1.00 & \\
{$[5]$} & EU accession & -0.36 & -0.27 & -0.40 & -0.44 & 1.00 \\
\hline
\end{tabular}

Notes: This table provides pairwise correlations for the 2004 values and 2004-2001 differences of our banklevel and country-level variables. Table 2 provides variable definitions and sources.

Table A3. Diagnostics of IV estimates in Models 2 and 7 in Table 4

\begin{tabular}{|c|c|c|c|c|c|c|}
\hline \multirow{3}{*}{$\begin{array}{l}\text { 2nd stage dependent } \\
\text { variable } \\
\text { 1st stage dependent } \\
\text { variable }\end{array}$} & \multicolumn{2}{|c|}{ Validity of instruments } & \multicolumn{4}{|c|}{ Strength of instruments } \\
\hline & \multirow[t]{2}{*}{$\begin{array}{l}\text { FX share } \\
\text { corporates }\end{array}$} & \multirow[t]{2}{*}{$\begin{array}{l}\text { FX share } \\
\text { households }\end{array}$} & \multicolumn{2}{|c|}{$\begin{array}{l}\text { FX share } \\
\text { corporates }\end{array}$} & \multicolumn{2}{|c|}{$\begin{array}{l}\text { FX share } \\
\text { households }\end{array}$} \\
\hline & & & $\begin{array}{l}\text { Wholesale } \\
\text { funding }\end{array}$ & $\begin{array}{c}\text { FX } \\
\text { deposits }\end{array}$ & $\begin{array}{l}\text { Wholesale } \\
\text { funding }\end{array}$ & $\begin{array}{c}\text { FX } \\
\text { deposits }\end{array}$ \\
\hline & (1) & (2) & (3) & (4) & (5) & (6) \\
\hline Foreign greenfield & $\begin{array}{c}5.955 \\
{[8.915]}\end{array}$ & $\begin{array}{r}0.227 \\
{[10.23]}\end{array}$ & $\begin{array}{l}14.31^{* * * *} \\
{[4.359]}\end{array}$ & $\begin{array}{c}2.750 \\
{[4.942]}\end{array}$ & $\begin{array}{l}15.50 * * * \\
{[4.456]}\end{array}$ & $\begin{array}{c}3.659 \\
{[4.922]}\end{array}$ \\
\hline Foreign takeover & $\begin{array}{l}12.93^{*} \\
{[6.784]}\end{array}$ & $\begin{array}{c}1.605 \\
{[7.529]}\end{array}$ & $\begin{array}{l}-1.028 \\
{[3.566]}\end{array}$ & $\begin{array}{c}-2.405 \\
{[4.320]}\end{array}$ & $\begin{array}{c}0.765 \\
{[3.604]}\end{array}$ & $\begin{array}{c}-3.095 \\
{[4.239]}\end{array}$ \\
\hline Assets & $\begin{array}{c}0.763 \\
{[1.678]}\end{array}$ & $\begin{array}{c}2.383 \\
{[2.526]}\end{array}$ & $\begin{array}{c}0.288 \\
{[0.933]}\end{array}$ & $\begin{array}{l}-1.531 \\
{[1.141]}\end{array}$ & $\begin{array}{c}0.149 \\
{[0.896]}\end{array}$ & $\begin{array}{c}-1.519 \\
{[1.115]}\end{array}$ \\
\hline Wholesale funding & $\begin{array}{l}0.316^{* *} \\
{[0.135]}\end{array}$ & $\begin{array}{l}0.372^{* *} \\
{[0.173]}\end{array}$ & & & & \\
\hline FX deposits & $\begin{array}{l}0.590^{* * * *} \\
{[0.0843]}\end{array}$ & $\begin{array}{l}0.694 * * * \\
{[0.0843]}\end{array}$ & & & & \\
\hline Corporate deposits & $\begin{array}{c}0.0034 \\
{[0.117]}\end{array}$ & $\begin{array}{l}0.15 \\
{[0.115]}\end{array}$ & $\begin{array}{c}0.039 \\
{[0.0744]}\end{array}$ & $\begin{array}{r}0.220^{* *} \\
{[0.0945]}\end{array}$ & $\begin{array}{c}0.050 \\
{[0.0783]}\end{array}$ & $\begin{array}{r}0.235 * * \\
{[0.0968]}\end{array}$ \\
\hline Internal ratings & $\begin{array}{r}-8.567 * \\
{[4.885]}\end{array}$ & $\begin{array}{l}-1.925 \\
{[4.964]}\end{array}$ & $\begin{array}{l}11.26^{* * * *} \\
{[3.346]}\end{array}$ & $\begin{array}{l}-2.350 \\
{[4.826]}\end{array}$ & $\begin{array}{l}10.82^{* * * *} \\
{[3.354]}\end{array}$ & $\begin{array}{l}-3.326 \\
{[4.798]}\end{array}$ \\
\hline Method & OLS & OLS & 2SLS & 2SLS & 2SLS & 2SLS \\
\hline $\begin{array}{l}\text { Country-fixed effects } \\
R^{2}\end{array}$ & $\begin{array}{l}\text { No } \\
0.29\end{array}$ & $\begin{array}{l}\text { No } \\
0.25\end{array}$ & $\begin{array}{l}\text { No } \\
0.15\end{array}$ & $\begin{array}{l}\text { No } \\
0.09\end{array}$ & $\begin{array}{l}\text { No } \\
0.16\end{array}$ & $\begin{array}{l}\text { No } \\
0.11\end{array}$ \\
\hline No. of banks & 155 & 151 & 155 & 155 & 151 & 151 \\
\hline $\begin{array}{l}F \text { test of Internal } \\
\text { ratings }=0 \text { and Corporate } \\
\text { deposits }=0 \text { ( } p \text {-value })\end{array}$ & 0.20 & 0.43 & 0.01 & 0.07 & 0.01 & 0.05 \\
\hline $\begin{array}{l}\text { Kleibergen-Paap rk } \\
\text { test ( } p \text {-value) }\end{array}$ & & & 0.04 & & 0.01 & \\
\hline
\end{tabular}

Notes: This table provides diagnostic tests related to the instrumentation strategy in Table 4. Columns 1 and 2 illustrate the absence of a statistically significant direct impact of the instruments Corporate deposits and Internal ratings on the share of FX lending. Columns 3 to 6 show the strong correlation between these two instruments and the endogenous variables Wholesale funding and $F X$ deposits, respectively, in the first-stage regressions. 


\section{REFERENCES}

Allayannis, G., G. Brown and L. Klapper (2003). 'Capital structure and financial risk: evidence from foreign debt use in East Asia', Fournal of Finance, 58, 2667-709.

Arteta, C.O. (2005). 'Exchange rate regimes and financial dollarisation: does flexibility reduce bank currency mismatches?', Berkeley Electronic Fournals in Macroeconomics, Topics in Macroeconomics, 5(1), Article 10.

Bakker, B.B. and A. Gulde (2010). 'The credit boom in the EU new member states: bad luck or bad policies?', IMF Working Paper No. 130, International Monetary Fund, Washington DC.

Barajas, A. and R.A. Morales (2003). 'Dollarisation of liabilities: beyond the usual suspects', IMF Working Paper No. 11, International Monetary Fund, Washington DC.

Basso, H., O. Calvo-Gonzalez and M. Jurgilas (2010). 'Financial dollarisation: the role of foreign-owned banks and interest rates', Fournal of Banking and Finance, 35, 794-806.

Beer, C., S. Ongena and M. Peter (2010). 'Borrowing in foreign currency: Austrian households as carry traders', Fournal of Banking E् Finance, 34, 2198-2211.

Benavente, J., C. Johnson and F. Morande (2003). 'Debt composition and balance sheet effects of exchange rate depreciations: a firm-level analysis for Chile', Emerging Markets Review, 4, 397-416.

Berger, A. and G. Udell (1998). 'The economics of small business finance: the roles of private equity and debt markets in the financial growth cycle', fournal of Banking \& Finance, 22, 613-73.

Brown, M., T. Jappelli and M. Pagano (2009a). 'Information sharing and credit: firm-level evidence from transition countries', Fournal of Financial Intermediation, 18, 151-72.

Brown, M., K. Kirschenmann and S. Ongena (2010). 'Foreign currency loans: demand or supply driven?', CEPR Discussion Paper No. 7952, London.

Brown, M., S. Ongena and P. Yesin (2009b). 'Foreign currency borrowing by small firms', Swiss National Bank Working Paper 2009-2.

Brown, M., S. Ongena and P. Yesin (2011). 'Foreign currency borrowing by small firms in the transition economies', Fournal of Financial Intermediation, 20, 285-302.

Brown, M., M. Peter and S. Wehrmüller (2009c). 'Swiss franc lending in Europe', Aussenwirtschaft, 64(2), 167-81.

Cetorelli, N. and L. Goldberg (2011). 'Global banks and international shock transmission: evidence from the crisis', International Monetary Fund Economic Review, 59(1), 41-46.

Cowan, K. (2006). 'Firm level determinants of dollar debt?', Central Bank of Chile, Working Paper.

Degryse, H., O. Havrylchyk, E. Jurzyk and S. Kozak (2011). 'Foreign bank entry, credit allocation, and lending rates in emerging markets: empirical evidence from Poland', Fournal of Banking and Finance, forthcoming.

De Haas, R., D. Ferreira and A. Taci (2010). 'What determines the composition of banks' loan portfolios? Evidence from transition countries', Journal of Banking and Finance, 34, 388-98.

De Haas, R. and I. Naaborg (2006). 'Foreign banks in transition countries: to whom do they lend and how are they financed?' Financial Markets, Institutions \&̊ Instruments, 15, 159-99.

De Haas, R. and I. Van Lelyveld (2006). 'Foreign banks and credit stability in Central and Eastern Europe: a panel data analysis.', Fournal of Banking and Finance, 30, 1927-52.

De Haas, R. and I. Van Lelyveld (2010). 'Internal capital markets and lending by multinational bank subsidiaries', Fournal of Financial Intermediation, 19, 1-25.

De Nicolo, G., P. Honohan and A. Ize (2005). 'Dollarisation of bank deposits: causes and consequences', Fournal of Banking \& Finance, 29, 1697-727.

Detragiache, E., T. Tressel and P. Gupta (2008). 'Foreign banks in poor countries: theory and evidence', Journal of Finance, 63, 2123-60.

European Bank for Reconstruction and Development (2010). Transition Report 2010. Recovery and Reform, London.

Fidrmuc, J., M. Hake and H. Stix (2011), 'Households' foreign currency borrowing in Central and Eastern Europe', mimeo.

Fries, S. and A. Taci (2005). 'Cost efficiency of banks in transition: Evidence from 289 banks in 15 post-communist countries', Journal of Banking and Finance, 29, 55-81. 
Froot, K. and R. Thaler (1990). 'Anomalies: foreign exchange', Fournal of Economic Perspectives, 4, 179-92.

Gelos, G. (2003). 'FX debt in emerging markets: firm-level evidence from Mexico', Economics Letters, 78, 323-27.

Goswami, G. and M.M. Shrikhande (2001). 'Economic exposure and debt financing choice', Fournal of Multinational Financial Management, 11, 39-58.

Havrylchyk, O. and E. Jurzyk (2010). 'Inherited or earned? Performance of foreign banks in Central and Eastern Europe', IMF Working Paper No. 04, International Monetary Fund, Washington DC.

Isard, P. (2006). 'Uncovered interest parity', IMF Working Paper No. 96, International Monetary Fund, Washington DC.

Ize, A. and E. Levy-Yeyati (2003). 'Financial dollarisation', Fournal of International Economics, $59,323-47$.

Kamil, H. (2009). 'How do exchange rate regimes affect firms' incentives to hedge currency risk in emerging markets?', Mimeo.

Kedia, S. and A. Mozumdar (2003). 'FX-denominated debt: an empirical examination', Journal of Business, 76, 521-46.

Keloharju, M. and M. Niskanen (2001). 'Why do firms raise FX denominated debt? European Financial Management, 7, 481-96.

Király, J., J. Antal, M. Nagy and V. Szabó (2009). 'Retail credit expansion and external finance in Hungary: lessons from the recent past (1998-2007)', BIS Papers No. 4, Bank for International Settlements, Basel.

Kokenyne, A., J. Ley and R. Veyrune (2010), 'Dedollarization', IMF Working Paper No. 188, International Monetary Fund, Washington DC.

Luca, A. and I. Petrova (2008). 'What drives credit dollarisation in transition economies? Fournal of Banking Ë Finance, 32, 858-69.

Martinez, L. and A. Werner (2002). 'The exchange rate regime and the currency composition of corporate debt: the Mexican experience', Journal of Development Economics, 69, 315-34.

Rancière, R., A. Tornell and A. Vamvakidis (2010). 'Currency mismatch and systemic risk in emerging Europe', Economic Policy, 64, October, 597-658.

Rosenbaum, P. and D. Rubin (1983). 'The central role of the propensity score in observational studies for causal effects', Biometrika, 70(1), 41-55.

Zettelmeyer, J., P. Nagy and S. Jeffrey (2010). 'Addressing private sector currency mismatches in emerging Europe', EBRD Working Paper No. 115, European Bank for Reconstruction and Development, London. 